\title{
A CORRELAÇÃO ENTRE A NOÇÃO DE SUBJETIVIDADE E O DESENVOLVIMENTO DO PROGRAMA DA FENOMENOLOGIA EM HUSSERL
}

The correlation between the notion of subjectivity and the development of the husserl's

phenomenology program

\author{
Adelar Conceição*
}

Resumo: O objetivo do presente artigo é assinalar a correlação entre a concepção de subjetividade e o desenvolvimento da fenomenologia enquanto projeto programático. Para isso, percorremos as diferentes fases da fenomenologia husserliana procurando destacar o papel crescente desempenhado pela subjetividade, tanto a partir da chamada "virada transcendental", quando ainda na etapa tardia da temática do "mundo da vida" (Lebenswelt). Por fim, procuramos mostrar que para a concepção de fenomenologia de Husserl permanece a referência última à subjetividade, pois ela é não só condição, mas também fundamento que confere unidade ao projeto geral da fenomenologia nas suas sucessivas etapas.

Palavras-chave: Subjetividade, Fenomenologia Transcendental, Mundo da Vida.

\begin{abstract}
The aim of this article is to point out the correlation between the conception of subjectivity and the development of phenomenology as a programmatic project. In order to do this, we go through the different phases of Husserlian phenomenology, seeking to highlight the growing role played by subjectivity, both from the so-called "transcendental turn" and even in the later stage of the "lifeworld" (Lebenswelt). Finally, we seek to show that Husserl's conception of phenomenology remains the ultimate reference to subjectivity, since it is not only a condition but also a foundation that gives unity to the general project of phenomenology in its successive stages.
\end{abstract}

Keywords: Subjectivity, Transcendental Phenomenology, Lifeworld.

* Doutorando em Filosofia pela Universidade Federal do Rio Grande do Sul - UFRGS. E-mail: adelarconceicao@hotmail.com

\begin{tabular}{|l|c|c|c|c|c|}
\hline intuitio & $\begin{array}{c}\text { ISSN } \\
1983-4012\end{array}$ & Porto Alegre & Vol.10- No.2 & $\begin{array}{c}\text { Dezembro } \\
2017\end{array}$ & p. 21-51 \\
\hline
\end{tabular}


A Correlação entre a Noção de Subjetividade e o Desenvolvimento do Programa da Fenomenologia em Husserl

\section{Introdução}

A relação entre a subjetividade e a fenomenologia como projeto programático em Husserl é algo que se torna claro à medida que esta se converte em metodologia de uma filosofia de orientação idealista transcendental, cujo pressuposto é, justamente, a subjetividade na figura do Ego cogito transcendental como o princípio de constituição de todo sentido que os fenômenos têm para a consciência pura.

Contudo, se esse paralelismo se torna fácil de assinalar a partir da "virada transcendental" da fenomenologia, por outro lado, ele não é algo dado de imediato quando consideramos a fenomenologia no seu conjunto, em particular na sua fase inicial e nos seus desdobramentos tardios. É assim que, para compreender como a noção de subjetividade permanece presente e determinante nas várias etapas da fenomenologia husserliana, nos parece necessário analisar o desenvolvimento da fenomenologia considerada no seu todo enquanto projeto programático. Através desse recurso poderemos então mostrar como a referência a subjetividade se afirma como pressuposto necessário, desde o caminho que leva da fenomenologia inicial ao idealismo transcendental fenomenológico, e ainda sua presença determinante na "fenomenologia constitutiva" e do "mundo da vida" (Lebenswelt).

Para tanto, como ponto de partida tomamos as análises consagradas a noção de Eu puro nas Investigações Lógicas (1900/01) para então mostrar sua retomada e papel crescente no primeiro volume das Ideias para uma Fenomenologia Pura e uma Filosofia Fenomenológica (1913) e nas Meditações Cartesianas (1931) na figura do Ego transcendental. Em um segundo momento nos concentramos nos problemas constitutivos da fenomenologia e do tema do mundo da vida, respectivamente no segundo volume das Ideias para uma Fenomenologia Pura e uma Filosofia Fenomenológica (1952) e na A Crise das Ciências Europeias e a Fenomenologia Transcendental (1936), analisando em que medida estes também se mostram dependentes de uma explicitação por meio da subjetividade transcendental. Através desse percurso esperamos destacar a relação do projeto fenomenológico com a referência indeclinável da subjetividade última da consciência.

\section{A evolução do programa da fenomenologia}

O projeto inicial da fenomenologia ${ }^{1}$ apresentado nas Investigações Lógicas (1900/01) está disposto em duas grandes partes, a primeira (tomo I) trata dos Prolegômenos a uma lógica pura, enquanto

\footnotetext{
${ }^{1}$ A obra de Husserl se prolonga em fases distintas geralmente dividida em quatro: a fase psicologista expressa em Sobre o Conceito de Número (1887) e Filosofia da Aritmética (1891), a fase inaugural da Fenomenologia ainda como "psicologia descritiva" das Investigações Lógicas (1900-01), a fase da Fenomenologia Transcendental iniciada em Ideias I (1913) e exemplificada de forma definitiva nas Meditações Cartesianas (1930) e, por último, a fase
}

\begin{tabular}{|l|c|l|l|c|c|}
\hline intuitio & $\begin{array}{c}\text { ISSN } \\
1983-4012\end{array}$ & Porto Alegre & Vol.10- $\mathrm{N}^{\mathrm{o} .2}$ & $\begin{array}{c}\text { Dezembro } \\
2017\end{array}$ & p. 21-51 \\
\hline
\end{tabular}


A Correlação entre a Noção de Subjetividade e o Desenvolvimento do Programa da Fenomenologia em Husserl

a segunda (tomo II) se refere às Investigações para a fenomenologia e a teoria do conhecimento. Pela divisão da obra é possível ter uma ideia da dimensão do projeto: trata-se do que se desdobrará posteriormente no programa de uma metodologia pura dos fundamentos do conhecimento, não apenas da filosofia, mas das ciências em geral.

Assim, os prolegômenos que se encontram na introdução das Investigações exemplificam de maneira clara a necessidade de executar primeiro uma limpeza do terreno da lógica ${ }^{2}$ para em seguida passar aos seus fundamentos teóricos, pois disto dependerá a possibilidade da teoria do conhecimento e consequentemente da própria objetividade do conhecimento. Desse modo, trata-se da contraposição entre duas concepções que consideram que ou "a lógica é uma disciplina teórica, independente da psicologia e ao mesmo tempo formal e demonstrativa, [...] [ou] uma tecnologia dependente da psicologia [...]"3. Ou seja, ou a encaramos como "disciplina apriorística e demonstrativa" ou como uma "disciplina empírica e indutiva".

Precisamente, o esforço inicial das Investigações é demonstrar que a "imperfeição teórica" das ciências em geral, exemplificado nos problemas de fundamentação da lógica e da teoria do conhecimento, deriva desse seu caráter fundado que as impede de levantar a pergunta pelos seus princípios apriorísticos. O matemático, o físico, o astrônomo, não necessitam recorrer aos fundamentos últimos de sua atividade para levar a bom termo seus trabalhos científicos, contudo, ficam assim impossibilitados de provar estes mesmos pressupostos sobre os quais repousa a validade de suas conclusões. Este trabalho caberia então a filosofia, e a fenomenologia mais especificamente, como método capaz de fazer a crítica ao psicologismo e fundar um campo puro de fenômenos.

\subsection{O papel do eu na fenomenologia das Investigações Lógicas}

Se mantivemos esse pano de fundo presente ao longo das Investigações, da necessidade de distinguir a fenomenologia enquanto campo de descrição dos fenômenos da consciência frente ao psicologismo que visa descrever essas mesmas operações em termos psíquicos, explica-se então a razão pela qual no Capítulo 1 da Quinta Investigação, referente às vivências intencionais e seus "conteúdos", intitulada A consciência como unidade fenomenológica do eu e a consciência como percepção interna,

tardia do tema do "mundo da vida" em A Crise das Ciências Europeias e a Fenomenologia Transcendental (1936). Para uma análise detalhada da cronologia e obras de Husserl, cf. SPIEGELBERG, Herbert. The phenomenological movement: a historical introduction. Boston: Martinus Nijhoff, 1982.

${ }^{2}$ O problema dos fundamentos da lógica já é discutido por Husserl na Filosofia da Aritmética de 1891, convergindo para o problema do fundamento da ciência, sua verdade e unidade. Contudo, diferente da posição adotada na obra anterior, onde se pretende uma redução do conceito de número ao resultado de operações subjetivas de ordem psíquica explicáveis pela psicologia, trata-se aqui justamente da crítica desta forma de psicologismo

${ }^{3}$ HUSSERL, Edmund. Investigaciones Lógicas. Madri: Revista do Ocidente, 1976, p. 38.

\begin{tabular}{|l|c|l|l|c|c|}
\hline intuitio & $\begin{array}{c}\text { ISSN } \\
1983-4012\end{array}$ & Porto Alegre & Vol.10- $\mathrm{N}^{\mathrm{o} .2}$ & $\begin{array}{c}\text { Dezembro } \\
2017\end{array}$ & p. 21-51 \\
\hline
\end{tabular}


A Correlação entre a Noção de Subjetividade e o Desenvolvimento do Programa da Fenomenologia em Husserl

Husserl se empenha em distinguir a concepção fenomenológica de consciência das demais concepções correntes. O problema da fenomenologia é justamente que a investigação acerca da essência fenomenológica dos atos desta ordem, guarda uma estreita relação com as pretensões de delimitar o terreno próprio da psicologia.

A psicologia, com efeito, entende por "vivências" e "conteúdos", acontecimentos reais que constituem a unidade real da consciência do indivíduo. Contudo, Husserl assinala a necessidade de distinguir o "conteúdo consciente na percepção" e "o objeto exterior percebido nela". Não se trata portanto de um mero "ponto de vista", como se fosse possível considerar ora o fenômeno na sua conexão subjetiva com a consciência, ora na sua conexão objetiva com as coisas mesmas. Husserl insiste sempre na necessidade de manter presente esta distinção, pois "não se poderá nunca assinalar com bastante rigor o equívoco que permite chamar fenômeno, não só à vivência em que se constitui o aparecer do objeto [...], senão também ao objeto aparecente como tal" ${ }^{\text {"4 }}$. Esta é, contudo, uma atitude natural se nos considerarmos unicamente como membros do mundo fenomênico, onde nos encontramos em meio às coisas em geral.

A intenção de Husserl é, portanto, evitar a confusão gerada por essa multiplicidade de sentidos do termo "consciência" e diferenciar o conceito fenomenológico de vivência do seu conceito popular. A consciência fenomenológica diferencia-se da consciência do eu empírico (sujeito psicofísico) no sentido em que o que chamamos de "vivido" (os objetos aparentes e processos externos enquanto fenômenos objetivos) não pode ser identificado com a consciência fenomenológica que os vive, que não possui em si estes processos como seus "componentes" e "conteúdos" reais.

Por isso, para a fenomenologia das Investigações, "o eu no seu sentido habitual é um objeto empírico", ou seja, esse "sujeito fenomênico" considerado dentro do complexo de relações do mundo fenomênico, como qualquer coisa física, está assim ao alcance da intervenção científica e, portanto, “[...] como todos os objetos desta índole, não têm fenomenologicamente outra unidade que a que lhe é dada pelas qualidades fenomênicas reunidas e se funda no conteúdo próprio destas" $"$. A ele corresponde outra unidade senão aquela que lhe é dada pela própria consciência, pois se separarmos o eu do seu conteúdo empírico descobrimos que a ele não corresponde nenhum "conteúdo" de consciência.

Se distinguimos o corpo do eu e o eu empírico, e restringimos o eu psíquico puro a seu conteúdo fenomenológico, o eu puro fica reduzido a unidade da consciência, ou seja, a compleição real das vivências, compleição que nós (isto é, cada um para o seu eu) encontramos, em parte, como existente com evidência em nós mesmos e admitimos com fundamento, pela outra parte complementar. $O$ eu, fenomenologicamente reduzido, não é, por isso, nada peculiar que flutue sobre as múltiplas vivências; é simplesmente idêntico a unidade sintética própria destas ${ }^{6}$.

\footnotetext{
${ }^{4}$ HUSSERL, Edmund. Investigaciones Lógicas. Madri: Revista do Ocidente, 1976, p. 478.

${ }^{5}$ Ibid., p. 480.

${ }^{6}$ HUSSERL, Edmund. Investigaciones Lógicas. Madri: Revista do Ocidente, 1976, p. 480, grifos nossos.
}

\begin{tabular}{|c|c|c|c|c|c|}
\hline intuitio & $\begin{array}{c}\text { ISSN } \\
1983-4012\end{array}$ & Porto Alegre & Vol.10 - No.2 & $\begin{array}{c}\text { Dezembro } \\
2017\end{array}$ & p. 21-51 \\
\hline
\end{tabular}


A Correlação entre a Noção de Subjetividade e o Desenvolvimento do Programa da Fenomenologia em Husserl

Os conteúdos próprios da consciência têm sua maneira peculiar de se unirem e se fundirem em unidades e assim constituem o "eu fenomenológico ou a unidade da consciência", sem a necessidade de pôr a par disso um princípio próprio como o eu, “[...] sujeito de todos os conteúdos e unificador de todos eles uma vez mais" "7. Para a fenomenologia das Investigações, seria incompreensível a função de tal princípio.

Tal crítica se estende também à análise do eu puro, o eu da "apercepção pura", que para muitos representa o ponto unitário de referência ao qual se refere todo conteúdo da consciência. Aqui, o posicionamento de Husserl contrasta com a defendida por Natorp. Para este "a consciência é referência ao eu", sendo "conteúdo", "tudo aquilo que está referido na consciência a um eu" e é justamente esta referência que constitui o "comum" e "específico" da consciência enquanto tal. Este eu é um "centro subjetivo de referência" embora, segundo Natorp, não possamos descrevê-lo nem a sua referência, pois "[...] toda representação que nos fizermos do eu converteria este em um objeto" ${ }^{\text {. }}$.

No entanto, como o próprio Husserl faz notar, como Natorp pretende fixar o que ele chama de "fato básico da psicologia" sem o pensarmos e sem assim convertê-lo num objeto? Com efeito, tal como as investigações sobre o eu empírico mostram que a ele não corresponde nenhum conteúdo real da consciência, para Husserl a concepção fenomenológica do eu não deixa lugar ao eu puro da percepção interna:

Agora bem, devo confessar que não logro encontrar de nenhuma maneira esse eu primitivo, centro necessário de referência. O único que sou capaz de notar ou de perceber é o eu empírico e sua referência empírica àquelas vivências próprias ou a aqueles objetos externos, que no momento dado se tornaram para ele justamente objetos de "atenção" especial, ficando "fora" e "dentro" muitas outras coisas que carecem desta referência ao eu'.

Portanto, o eu puro enquanto "centro necessário de referência" carece, justamente, de uma referência, uma vez que a ele não corresponde nenhum "objeto" como no caso do eu empírico.

Por outro lado, a análise fenomenológica do eu empírico mostra que não é possível compreender a referência do eu aos seus objetos senão como pertencente à consciência total daquelas vivências intencionais cujo objeto é "o corpo do eu”, "o eu como pessoa espiritual” e "o sujeito eu empírico inteiro (eu, homem)". E se por "conteúdo" se entende qualquer objeto ao qual se dirija a consciência em forma de percepção, imaginação, representação e assim por diante, então compreende-se que "[...] a autoapercepção do eu empírico é uma experiência de todos os dias, que não oferece dificuldades de compreensão. $O$ eu é percebido do mesmo modo que qualquer coisa externa ${ }^{10}$.

\footnotetext{
${ }^{7}$ HUSSERL, Edmund. Investigaciones Lógicas. Madri: Revista do Ocidente, 1976, p. 480-481.

${ }^{8}$ Ibid., 484-485.

${ }^{9}$ HUSSERL, Edmund. Investigaciones Lógicas. Madri: Revista do Ocidente, 1976, p. 485.

${ }^{10}$ Ibid., p. 486, grifos nossos.
}

\begin{tabular}{|l|c|c|c|c|c|}
\hline intuitio & $\begin{array}{c}\text { ISSN } \\
1983-4012\end{array}$ & Porto Alegre & Vol.10- No.2 & $\begin{array}{c}\text { Dezembro } \\
2017\end{array}$ & p. 21-51 \\
\hline
\end{tabular}


A Correlação entre a Noção de Subjetividade e o Desenvolvimento do Programa da Fenomenologia em Husserl

Assim, através dessa breve análise, podemos constatar que no programa nascente da fenomenologia o eu não ocupa um papel de ponto de referência da consciência. Contudo, esta concepção sofrerá uma mudança radical a partir do momento em que Husserl encaminha a fenomenologia na direção de uma filosofia transcendental. Numa nota a segunda edição das Investigações em 1913, Husserl ressalta que já não aprova o que havia anteriormente dito com relação ao eu puro:

Nota à segunda edição - fazemos notar expressamente que a posição aqui defendida na questão do eu puro - posição que já não aprovo, como fica dito - resulta de pouca ou nenhuma importância para as investigações deste tomo. Por mais importante que esta questão seja, inclusive como questão fenomenológica pura, há esferas sumamente amplas de problemas fenomenológicos que concernem com certa generalidade ao conteúdo real das vivências intencionais e a sua referência essencial aos objetos intencionais; e essas esferas podem ser submetidas a uma investigação sistemática, sem necessidade de tomar em geral posição frente a questão do eu. As presentes investigações se referem exclusivamente a estas esferas ${ }^{11}$.

Portanto, se nas Investigações Husserl se preocupa com uma esfera de problemas mais amplos, ainda no campo próximo de uma psicologia descritiva, posteriormente, como veremos, o projeto fenomenológico se encaminha na direção de uma análise da consciência transcendental e assim à necessidade de reconsiderar o problema do eu. Neste processo a concepção de eu puro, através de sucessivas reduções fenomenológicas, revela-se o campo puro da fenomenologia transcendental e o princípio de constituição de todo sentido.

Mas, justamente, quais os motivos dessa virada transcendental? Por qual razão o eu puro, do qual, como vimos, não podemos encontrar uma referência nem função no quadro da fenomenologia descritiva, se transmuta em algo necessário a uma nova fenomenologia e filosofia como ciências de rigor? Para dar respostas a essas questões é que nos parece necessário analisar o paralelismo entre o desenvolvimento do programa da fenomenologia e o papel nele assumido pela subjetividade na figura do Ego transcendental.

\section{$1.2 O$ desenvolvimento da concepção de fenomenologia em Husserl}

Assim, desde a publicação das Investigações Lógicas, o programa da fenomenologia sofreu alterações drásticas. Levado cada vez mais pela exigência de rigor e a necessidade de fundar um campo que escapasse a, ainda, "psicologia descritiva" das Investigações, Husserl se empenha em fazer da fenomenologia a ciência pura dos princípios, a única a alcançar o domínio transcendental. Em 1907, em trabalhos como A fenomenologia como ciência de rigor e A ideia da fenomenologia, a fenomenologia já é

\footnotetext{
${ }^{11}$ HUSSERL, Edmund. Investigaciones Lógicas. Madri: Revista do Ocidente, 1976, 486-487.
}

\begin{tabular}{|c|c|c|c|c|c|}
\hline intuitio & $\begin{array}{c}\text { ISSN } \\
1983-4012\end{array}$ & Porto Alegre & Vol.10- No.2 & $\begin{array}{c}\text { Dezembro } \\
2017\end{array}$ & p. 21-51 \\
\hline
\end{tabular}


A Correlação entre a Noção de Subjetividade e o Desenvolvimento do Programa da Fenomenologia em Husserl

apresentada como "fenomenologia transcendental" 12 , e, finalmente, em 1913 Husserl publica o primeiro volume das Ideias para uma Fenomenologia Pura e uma Filosofia Fenomenológica.

O título da obra já informa que a "fenomenologia pura" possui não apenas uma posição singular com relação as ciências mas deve se firmar também como "a ciência fundamental da filosofia". Com efeito, na introdução Husserl fala da necessidade de evitar certas interpretações errôneas que desde as Investigações Lógicas veem a fenomenologia como "prelúdio da psicologia empírica", cuja esfera de descrições "imanentes" abarca vivências psíquicas que se mantém "rigorosamente dentro do marco da experiência interna" ${ }^{\prime 13}$. Assim, um dos esforços de Husserl nas Ideias será justamente mostrar que a fenomenologia pura não é psicologia.

O primeiro livro das Ideias (o único publicado por Husserl em vida) ocupa-se da tarefa de preparar a entrada neste "novo mundo" que é a fenomenologia transcendental. O ponto de partida será a "posição natural”, na qual nos encontramos com a crença na existência do mundo, como a consciência se dá na experiência psicológica, para mostrar os "erros fundamentais" desta posição. Em seguida Husserl desenvolve o método de "reduções fenomenológicas", pelo qual pretende "superar os limites impostos ao conhecimento pela essência de toda forma de investigação natural", ao evitar que se dirija o olhar unicamente na direção dos fenômenos da posição natural para assim "ganhar o livre horizonte dos fenômenos purificados 'transcendentalmente', e com ele o campo da fenomenologia no sentido que nos é peculiar" ". A novidade contida nas Ideias é portanto o recurso a "redução fenomenológica". Através dela é que Husserl espera poder alcançar o verdadeiro campo transcendental e liberar a fenomenologia do terreno da psicologia descritiva.

A nova fenomenologia transcendental se caracterizará não como uma "ciência de fatos", mas como uma "ciência de essências", eidética. A epoché ou redução fenomenológica consiste na abstração de todo sentido dos fenômenos do mundo "real", do eu empírico e seu mundo circundante, para ascender às camadas superiores da experiência pura transcendental, onde resta o "eu puro" como resíduo. Este aspecto aparece em relevo nas Meditações Cartesianas, onde o Ego transcendental liberado pela redução aparece como o princípio de constituição de todo sentido.

As Meditações Cartesianas, Introdução a Fenomenologia, trabalho de maturidade (final dos anos 20), é considerada por Husserl sua obra definitiva que prolongou, reelaborou, mas não chegou a levar a cabo por completo. Composta de cinco meditações, só foi publicada, na integra, postumamente nas

\footnotetext{
${ }^{12}$ A Ideia da Fenomenologia, introdução de um texto de Husserl de 1907, apresenta pela primeira vez de forma temática a ideia de redução fenomenológica.

13 HUSSERL, Edmund. Ideas Relativas a una Fenomenología Pura y una Filosofía Fenomenológica. Libro Primero: Introduccción general a la fenomenologia pura. México, D.F.: Fondo de Cultura Econômica, 1986, p. 7.

${ }^{14}$ Ibid., p. 9.
}

\begin{tabular}{|c|c|c|c|c|c|}
\hline intuitio & $\begin{array}{c}\text { ISSN } \\
1983-4012\end{array}$ & Porto Alegre & Vol.10-N $\mathrm{N}^{\mathrm{o}} .2$ & $\begin{array}{c}\text { Dezembro } \\
2017\end{array}$ & p. 21-51 \\
\hline
\end{tabular}


A Correlação entre a Noção de Subjetividade e o Desenvolvimento do Programa da Fenomenologia em Husserl

Husserliana, embora a versão francesa, traduzida por Pfeiffer e Levinas, já fosse conhecida antes da publicação da original.

Nas Meditações, vemos acentuada a proximidade da Fenomenologia Transcendental com Descartes e Leibniz, conforme Husserl havia anunciado nas Conferências de Paris (1929). Na introdução da obra, Husserl pergunta-se mesmo se a grande contribuição para a contemporaneidade não estará em reviver, ainda que no espírito, o pensamento cartesiano das Meditações Metafísicas. Pelo estudo das Meditações, Husserl o diz, a fenomenologia transforma-se "num tipo novo de filosofia transcendental" pelo "retorno radical ao ego cogito puro" ${ }^{15}$. Husserl apresenta as meditações de Descartes como "protótipo do retorno do filósofo sobre si mesmo" de modo que, os "novos impulsos" recebidos pela fenomenologia, a transformam num tipo novo de filosofia transcendental que, segundo o autor, quase poderíamos chamar de "neo-cartesianismo", onde Descartes surge como sendo o pai primitivo da fenomenologia.

Simultaneamente, as Meditações Cartesianas visam mostrar que o "Eu puro" da fenomenologia transcendental, embora constitua todo o horizonte de sentido do mundo, nem por isso se torna solipsista. Pelo contrário o grande esforço de Husserl na Quinta Meditação (que ocupa quase metade da obra) será mostrar como constituo no meu Ego transcendental reduzido a experiência do outro, ou seja, como se forma uma comunidade de mônadas, uma "intersubjetividade monádica".

Paralelamente, a contribuição das Meditações no conjunto da obra de Husserl se insere no sentido de acentuar a proximidade da fenomenologia transcendental com o Idealismo - conforme indicava as Ideias (1913) - confirmando-se definitivamente, como o próprio autor afirma, como um idealismo transcendental.

\subsection{A concepção de Eu na fenomenologia transcendental}

Embora as Meditações Cartesianas de Husserl tenham inspiração nas Meditações de Descartes, no retorno à evidência primeira do cogito, a concepção fenomenológica do Eu difere substancialmente da versão cartesiana. Husserl critica Descartes, sobretudo por não ter sido mais radical no caminho aberto pelo Eu Penso e, em consequência disto, ter sofrido a influência externa de pressuposto herdados de uma certa concepção matemática sobre os princípios da filosofia e os fundamentos de uma ciência pura.

As Meditações de Descartes visam uma reforma da filosofia, para fundá-la como uma ciência absoluta, o que significa para Descartes uma reforma de todas as ciências, já que para este elas não passam de ramificações de uma única ciência universal que é a filosofia. Por isso é necessário à filosofia, enquanto unidade universal das ciências, estar assentada sobre um princípio de caráter indubitável. A forma e o caráter deste primeiro axioma buscado pelo filósofo se realizam, em Descartes, como sabemos,

${ }^{15}$ HUSSERL, Edmund. Meditações Cartesianas. Introdução à Fenomenologia. Porto: Rés, 2001, p. 9:15.

\begin{tabular}{|l|c|c|c|c|c|}
\hline intuitio & $\begin{array}{c}\text { ISSN } \\
1983-4012\end{array}$ & Porto Alegre & Vol.10 - No.2 & $\begin{array}{c}\text { Dezembro } \\
2017\end{array}$ & p. 21-51 \\
\hline
\end{tabular}


A Correlação entre a Noção de Subjetividade e o Desenvolvimento do Programa da Fenomenologia em Husserl

baseado numa filosofia orientada para ao sujeito. Tomado do espírito de que este assunto é algo pessoal do filósofo, a tarefa consistirá na destruição de tudo aquilo que se acreditava como certo, todas as ciências até aí admitidas como verdadeiras e tentar reconstruí-las sobre bases sólidas ${ }^{16}$, onde ele deve poder justificar cada etapa, desde a sua origem, apoiando-se em intuições absolutas.

A aplicação desta crítica metódica à certeza da experiência sensível, mostra que o mundo organizado como dado empírico não resiste à crítica. Tudo aquilo que faz referência a existência deve portanto ser posto em suspenso logo de início. "Enquanto realidade absoluta e indubitável, o sujeito que medita retém apenas a si mesmo enquanto ego puro das suas cogitationes, como existindo indubitavelmente e não podendo ser suprimido mesmo que este mundo não exista" ${ }^{\prime 17}$. $\mathrm{O}$ eu assim reduzido alcança o seu caráter apodítico e encontra nessa "interioridade pura" a "exterioridade objetiva".

Para Husserl, tal como nas meditações cartesianas, tudo isto se faz num retorno ao "eu do filósofo" ${ }^{18}$, mas, como veremos, num sentido bem mais radical do que aquele proposto por Descartes.

\subsection{O caminho para o 'Ego transcendental'}

O retorno ao ego cogito que, segundo Husserl, nos leva a subjetividade transcendental, segue em paralelo as meditações desencadeadas pela "dúvida metódica" do francês. Isto significa em primeiro lugar que ficam em suspenso a verdade dos dados da ciência e a existência do mundo, fundada na experiência natural, pois este mundo nada mais é do que um fenômeno com "pretensão de existência". Assim como em Descartes não temos de início nem uma ciência válida nem um mundo existente. Com isto fica em suspenso também a existência de outros "Eu" que fazem parte do "mundo envolvente" e com eles desaparecem também todas as formas sociais e culturais. "Em suma, não só a natureza corporal, mas também o conjunto do mundo concreto que me rodeia já não é para mim, de ora em diante, um mundo existente, mas apenas 'fenômeno de existência","19.

Acontece que este fenômeno, independente do que resulte da sua "pretensão de existência", não se tornou por isso um "puro nada". Permanece a possibilidade de dizer algo verdadeiro a respeito dele, ou seja, nada é afirmado contra a validade do fenômeno. Ainda que me abstenha da crença na existência de

16 “E, para isso, não é necessário que examine cada uma em particular, o que seria um trabalho infinito; mas, visto que a ruína dos alicerces carrega necessariamente consigo todo o resto do edifício, dedicar-me-ei inicialmente aos princípios sobre os quais todas as minhas antigas opiniões estavam apoiadas" (DESCARTES, 1973, p. 93).

${ }^{17}$ HUSSERL, Edmund. Meditações Cartesianas. Introdução à Fenomenologia. Porto: Rés, 2001, p. 12.

18 "Se considerarmos agora o conteúdo das Meditações, bem estranho para nós, encontramos aí um segundo retorno ao eu do filósofo, num sentido novo e mais profundo: o retorno ao eu das cogitationes puras. Este retorno é operado pelo método muito conhecido e assaz estranho da dúvida. Tendo apenas como objetivo o conhecimento absoluto, interdiz-se de admitir como existente o que não está inteiramente ao abrigo de qualquer possibilidade de ser posto em dúvida." (HUSSERL, 2001, p. 11).

${ }^{19}$ HUSSERL, Edmund. Meditações Cartesianas. Introdução à Fenomenologia. Porto: Rés, 2001, p. 31.

\begin{tabular}{|l|c|l|l|c|c|}
\hline intuitio & $\begin{array}{c}\text { ISSN } \\
1983-4012\end{array}$ & Porto Alegre & Vol.10- $\mathrm{N}^{\mathrm{o} .2}$ & $\begin{array}{c}\text { Dezembro } \\
2017\end{array}$ & p. 21-51 \\
\hline
\end{tabular}


A Correlação entre a Noção de Subjetividade e o Desenvolvimento do Programa da Fenomenologia em Husserl

um mundo empírico, ele permanece "aí para mim" presente no campo da percepção. Por isso a qualquer momento é possível, na reflexão, voltar-se a atenção sobre esta "vida espontânea" e alcançar este fenômeno com sua "validade concreta" tal como se se trata-se de um existente do mundo empírico. E isto, segundo Husserl, faço-o enquanto "eu” filosófico que pratica a abstenção.

Este é o resultado da "epoché fenomenológica", a operação metódica que "coloca entre parêntesis" a tese do mundo objetivo, o método pelo qual "me capto como eu puro", no qual o mundo é "o que existe e vale para minha consciência num tal cogito" ${ }^{20}$. Assim como ocorre com a "dúvida metódica" de Descartes, através da epoché o "mundo", e todo conjunto de fenômenos que ele designa, existe e tem validade para mim pelo fato de que dele tenho experiência num tal cogito. Nada do que possa viver, experimentar, pensar, em resumo todo juízo que pressuponha o mundo, só pode encontrar em mim o seu sentido e sua validade. Ao efetuar a abstenção sobre qualquer juízo que pressupõe a crença na existência do mundo, encontro-me unicamente como um ego puro com a corrente das minhas cogitationes.

Por consequência, de fato, a existência natural do mundo - do mundo acerca do qual eu posso falar - pressupõe, como uma existência em si anterior, a do ego puro e das suas cogitationes. O domínio da existência natural tem apenas uma autoridade de segunda ordem e pressupõe sempre o domínio transcendental ${ }^{21}$.

Acompanhando a reflexão de Descartes nas Meditações, pelo recurso a epoché, Husserl alcança o caráter indubitável do cogito como eu puro. Contudo, precisamente neste ponto Husserl nos adverte que devemos evitar a "tendência para encarar o ego cogito como um 'axioma' apodítico" a partir do qual se poderiam deduzir todos os demais axiomas fundamentais sobre os quais se fundariam os princípios de uma ciência explicativa do mundo, à maneira das ciências matemáticas. Esta concepção acaba levando Descartes a interpretar o "eu" como uma "qualquer coisa que pensa" 22 , uma substância finita que por sua vez requer a existência de uma substancia infinita, pela qual é continuamente recriada. Descartes deduz em primeiro lugar a existência e veracidade de Deus, e dele a garantia da natureza objetiva, a dualidade das substancias finitas, o terreno objetivo da metafísica e das ciências positivas ${ }^{23}$. Contudo, para a fenomenologia o que esta em vista não é uma prova da existência de Deus, mas a delimitação de uma esfera transcendental pura na qual se trata de recriar o modo como o mundo aparece na minha própria experiência que é a determinação daquilo que o mundo (em geral) é para mim.

Portanto se para Descartes o resultado desta operação faz do Ego uma "substantia cogitans separada", para Husserl, ao contrário, o "Eu transcendental” revelado pela redução (epoché) do eu natural,

\footnotetext{
${ }^{20}$ HUSSERL, Edmund. Meditações Cartesianas. Introdução à Fenomenologia. Porto: Rés, 2001, p. 33.

${ }^{21}$ Ibid., p. 34.

22 "Nada admito agora que não seja necessariamente verdadeiro: nada sou, pois, falando precisamente, senão uma coisa que pensa, isto é, um espírito, um entendimento ou uma razão, que são termos cuja significação me era anteriormente desconhecida. Ora, eu sou uma coisa verdadeira e verdadeiramente existente; mas que coisa? Já o disse: uma coisa que pensa" (DESCARTES, 1973, p. 102).

${ }^{23}$ HUSSERL, Edmund. Meditações Cartesianas. Introdução à Fenomenologia. Porto: Rés, 2001, p. 11-12.
}

\begin{tabular}{|c|c|c|c|c|c|}
\hline intuitio & $\begin{array}{c}\text { ISSN } \\
1983-4012\end{array}$ & Porto Alegre & Vol.10 - No.2 & $\begin{array}{c}\text { Dezembro } \\
2017\end{array}$ & p. 21-51 \\
\hline
\end{tabular}


A Correlação entre a Noção de Subjetividade e o Desenvolvimento do Programa da Fenomenologia em Husserl

quer dizer, do eu psíquico e psicofísico, conserva a experiência do mundo enquanto correlato da consciência transcendental.

Correlativamente não se deverá pensar seja a que título for que, no nosso eu puro apodítico, tenhamos conseguido salvar uma pequena parcela do mundo, parcela que, para o eu filosófico, seria a única coisa do mundo não sujeita a dúvida, e que se trata agora de reconquistar, através de deduções bem conduzidas e segundo os princípios inatos do ego, o resto do mundo ${ }^{24}$.

Husserl censura Descartes por este não ter se conformado inteiramente ao princípio de não enunciar aquilo que não se dê claramente na intuição pura do ego cogito. Por isso, embora Descartes tenha feito "a maior das descobertas", não conseguiu, segundo Husserl, apreender-lhe o verdadeiro sentido, o da subjetividade transcendental. E assim, "não atravessou o pórtico que conduz à filosofia transcendental verdadeira" ${ }^{25}$.

Com efeito, se pela epoché me capto como "eu" próprio com a minha vida própria intactos, independente de qualquer posição referente à existência do mundo empírico, já não me capto como "homem natural". O eu humano natural, da vida psíquica, é reduzido ao eu transcendental e fenomenológico, e todo o sentido e valor existencial que o mundo tem para mim, "extrai-os do meu $\mathrm{eu}$ transcendental que é único que revela a epoché fenomenológica transcendental" ${ }^{26}$. Husserl ressalta desta maneira que o próprio conceito de "transcendental", e correlativamente também o conceito de "transcendente", retiram o seu significado da meditação empreendida dentro da esfera da subjetividade transcendental. Finalmente este eu "que traz o mundo em si a título de unidade de sentido", se caracteriza como "transcendental no sentido fenomenológico desse termo", e seus problemas correlatos: "problemas filosóficos transcendentais"27.

\section{A Fenomenologia como "Egologia Transcendental"}

\subsection{A Epoché fenomenológica}

A grande pretensão de Husserl era colocar a Filosofia no caminho seguro de uma ciência, para isto era necessário um objeto próprio e um método que a elevasse ao status de ciência de rigor. Levado cada vez mais por esta exigência, Husserl empenha-se no projeto de fazer da Fenomenologia uma Filosofia Transcendental. Para satisfazer este ideal, a introdução do recurso da "redução" tem como objetivo elevar a investigação acima da esfera das simples opiniões, atendo-se a descrição do dado intuitivo. A redução se

\footnotetext{
${ }^{24}$ HUSSERL, Edmund. Meditações Cartesianas. Introdução à Fenomenologia. Porto: Rés, 2001, p. 37.

${ }^{25}$ Ibid., p. 38.

${ }^{26}$ HUSSERL, Edmund. Meditações Cartesianas. Introdução à Fenomenologia. Porto: Rés, 2001, p. 39

${ }^{27}$ Ibid., p. 40.
}

\begin{tabular}{|l|c|l|l|c|c|}
\hline intuitio & $\begin{array}{c}\text { ISSN } \\
1983-4012\end{array}$ & Porto Alegre & Vol.10- $\mathrm{N}^{\mathrm{o} .2}$ & $\begin{array}{c}\text { Dezembro } \\
2017\end{array}$ & p. 21-51 \\
\hline
\end{tabular}


A Correlação entre a Noção de Subjetividade e o Desenvolvimento do Programa da Fenomenologia em Husserl

encarrega do acesso a um fenômeno puro. De modo que o seu "retorno redutivo" se consumará ao cabo como um avanço exploratório.

A Epoché $e^{28}$ ou "redução" fenomenológica, que consiste na suspensão de qualquer juízo sobre o mundo natural, pretende romper com qualquer referência ao psíquico e alcançar o campo seguro da consciência transcendental, uma vez que a consciência em "atitude natural" vê a si própria como realidade do mundo, determinada pela causalidade física, biológica, cultural. Husserl caracteriza a epoché também como "[...] o método universal e radical pelo qual me capto como eu puro, com a vida da consciência pura que me é própria, vida na qual e pela qual o mundo objetivo na sua totalidade existe para mim, exatamente tal como existe para mim"29. Por esta razão a operação da redução fenomenológica inibe o "valor existencial" do mundo objetivo e assim também de qualquer juízo sobre ele. Husserl reafirma, nas Meditações Cartesianas, que aquele que desconhece o sentido e a função da redução fenomenológica transcendental encontra-se ainda no terreno do "psicologismo transcendental" 30 . Diferente da versão primitiva da fenomenologia como psicologia descritiva, a introdução da epoché tem por objetivo não apenas descrever as vivências enquanto estas aparecem a uma consciência, pois a fenomenologia transcendental deve ser, além disso, o correlato da descrição do campo de uma consciência enquanto esta constitui os seus objetos intencionais.

Neste caso a epoché fenomenológica adquiri uma importância redobrada uma vez que é por meio dela que a fenomenologia pode firmar-se no terreno de uma filosofia transcendental. Assim, em lugar da dúvida universal cartesiana, Husserl coloca a "epoché universal”, porém em um sentido preciso:

Pomos fora de jogo a tese geral inerente a essência da atitude natural. Colocamos entre parênteses toda e cada uma das coisas abarcadas em sentido ôntico por essa tese, assim, pois, este mundo natural inteiro, que esta constantemente 'para nós aí diante', e que seguirá estando permanentemente, como 'realidade' de que temos consciência, ainda que possamos colocar-lho entre parêntesis ${ }^{31}$.

A epoché diz respeito, portanto primeiramente a tese da atitude natural sobre a existência do mundo. Mas isto não significa por outro lado que esteja negando a existência deste mundo como o cético, “[...] senão que pratico a $\varepsilon \pi \circ \chi \eta$ 'fenomenológica' que me impede completamente todo juízo sobre existências no espaço e no tempo" ${ }^{\text {32 }}$. Do mesmo modo, todas as ciências que se referem a este mundo natural, que tem por base a experiência de objetos nele existentes, tem sua "validade" posta entre

28 Do grego $\varepsilon \pi \circ \chi \eta$, termo utilizado pelos céticos para designar a "suspensão do juízo" acerca da possibilidade de um conhecimento qualquer.

${ }^{29}$ HUSSERL, Edmund. Meditações Cartesianas. Introdução à Fenomenologia. Porto: Rés, 2001, p. 33, grifos nossos.

${ }^{30}$ Ibid., p. 112.

${ }^{31}$ HUSSERL, Edmund. Ideas Relativas a una Fenomenología Pura y una Filosofía Fenomenológica. Libro Primero: Introduccción general a la fenomenologia pura. México, D.F.: Fondo de Cultura Econômica, 1986, p. 73.

${ }^{32}$ Ibid., p. 73.

\begin{tabular}{|l|c|l|l|c|c|}
\hline intuitio & $\begin{array}{c}\text { ISSN } \\
1983-4012\end{array}$ & Porto Alegre & Vol.10- $\mathrm{N}^{\mathrm{o} .2}$ & $\begin{array}{c}\text { Dezembro } \\
2017\end{array}$ & p. 21-51 \\
\hline
\end{tabular}


A Correlação entre a Noção de Subjetividade e o Desenvolvimento do Programa da Fenomenologia em Husserl

parênteses. Ou seja, toda proposição que afirma algo sobre o mundo baseado na atitude natural, deve se tratada como uma proposição que pretende ser válida, e cuja validez deve ser analisada.

Finalmente através da epoché se alcança o campo da consciência pura, o domínio do eu transcendental:

Pela $\varepsilon \pi \circ \chi \eta$ fenomenológica, reduzo o meu eu humano natural e a minha vida psíquica domínio da minha experiência psicológica interna - ao meu eu transcendental e fenomenológico, domínio da experiência interna transcendental e fenomenológica. O mundo objetivo que existe para mim, que existiu ou que existirá para mim, este mundo objetivo com todos os seus objetos extrai de mim mesmo, afirmei-o mais acima, todo o sentido e todo o valor existencial que tem para mim; extrai-os do meu eu transcendental

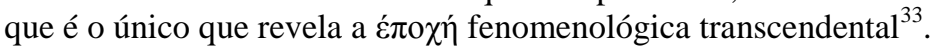

O propósito de Husserl é mostrar que a consciência "tem em si um ser próprio" que não é afetado pela redução, que permanece como "resíduo fenomenológico" e constitui uma região de ser que é precisamente o campo de atuação da fenomenologia. Por esta razão a epoché fenomenológica se justifica como '[...] a operação necessária para fazermos acessivel à consciência 'pura' e, conseqüentemente, a região fenomenológica inteira",34. À consciência pura Husserl chamará "consciência transcendental" e a operação através da qual se poderá alcançá-la de "epoché transcendental" "35.

\subsection{O Ego transcendental como princípio de constituição do mundo}

Husserl nos fala que é possível apreender o sentido da epoché fenomenológica, mas não a sua possível ação, pois não está da mesma forma delimitado o alcance da sua universalidade. Neste caso a pergunta que agora se apresenta é a seguinte: “Que pode, com efeito, restar, quando pomos em suspenso o mundo inteiro, incluindo nós mesmos com todo cogitare?"36.

Porém, se se espera que, ao pô-lo em suspenso, sucumba o mundo como um "fato", o mesmo não se pode dizer do mundo como "eidos", quer dizer, naquilo que lhe é próprio enquanto fenômeno. Esta meta que Husserl se refere indiretamente é "a conquista de uma nova região de ser" segundo ele ainda "não desvendada no que tem de própria". Por outro lado este trabalho se faz assinalando de forma direta o que constitui este ser que não é outra coisa senão o que se designa por “[...] 'vivências puras', 'consciência pura', com seus 'correlatos puros' e, por outra parte, seu 'eu puro' desde $o$ eu, desde $a$ consciência, as vivências que se nos dão na atitude natural’"37. Em outras palavras, Husserl reafirma sempre que o

\footnotetext{
${ }^{33}$ HUSSERL, Edmund. Meditações Cartesianas. Introdução à Fenomenologia. Porto: Rés, 2001 , p. 39.

34 HUSSERL, Edmund. Ideas Relativas a una Fenomenología Pura y una Filosofía Fenomenológica. Libro Primero: Introduccción general a la fenomenologia pura. México, D.F.: Fondo de Cultura Econômica, 1986, p. 76.

${ }^{35}$ Ibid., p. 76-77.

36 HUSSERL, Edmund. Ideas Relativas a una Fenomenología Pura y una Filosofía Fenomenológica. Libro Primero: Introduccción general a la fenomenologia pura. México, D.F.: Fondo de Cultura Econômica, 1986, p. 75.

${ }^{37}$ Ibid., p. 75.
}

\begin{tabular}{|l|c|c|c|c|c|}
\hline intuitio & $\begin{array}{c}\text { ISSN } \\
1983-4012\end{array}$ & Porto Alegre & Vol.10- No.2 & $\begin{array}{c}\text { Dezembro } \\
2017\end{array}$ & p. 21-51 \\
\hline
\end{tabular}


A Correlação entre a Noção de Subjetividade e o Desenvolvimento do Programa da Fenomenologia em Husserl

'mundo', que compreende todo ser espacial e temporal, existe para mim e 'vale' pelo fato mesmo que tenho dele experiência, como no cogito de Descartes, e posso dessa maneira emitir sobre ele juízos de existência e valor. Assim 'o mundo' é para mim tudo aquilo que tenho consciência num tal cogito, e isto a tal ponto que "não posso viver, experimentar, pensar; não posso agir e emitir juízos de valor num mundo diferente daquele que encontra em mim e extrai de mim mesmo o seu sentido e a sua validade ${ }^{38}$. Mais do que revelar um campo purificado de fenômenos, a consciência pura, o ego transcendental, afirma-se como aquele que constitui a nossa experiência do mundo, na medida em que somente a partir dele extraímos o seu sentido.

A 'existência' do ego transcendental modifica radicalmente o tipo de relação da consciência com o mundo: "por consequência, de fato, a existência natural do mundo - do mundo acerca do qual eu posso falar - pressupõe, como uma existência em si anterior, a do ego puro e suas cogitationes"39. O mundo é, portanto um fenômeno transcendente cujas 'partes reais' não tem lugar dentro na consciência transcendental, do mesmo modo como o eu reduzido não faz parte do mundo. Esta 'transcendência do mundo' se mostra no texto de Husserl pela oposição entre "o ser meramente fenomênico do transcendente e o ser absoluto do imanente", a "indubitabilidade da percepção imanente, dubitabilidade da transcendente" ${ }^{, 0}$, ou seja, o mundo natural como correlato da consciência pura transcendental e a impossibilidade de um mundo fora da esfera absoluta do ego transcendental.

A oposição entre a tese contingente do mundo e a tese necessária, "absolutamente indubitável", do eu e da vida do eu, resulta por fim na afirmação da 'consciência absoluta' como resíduo da "aniquilação do mundo":

Pois a aniquilação do mundo não quer dizer correlativamente senão que em toda corrente de vivências (a corrente total e plena das vivências de um eu, tomada, pois, sem termo por nenhum dos seus dois lados) ficariam excluídas certas ordens de experiências e por conseguinte certas ordens da razão teorizante que busca sua orientação nelas. [...] Assim, pois, nenhum ser real em sentido estrito, nenhum ser que se exiba e comprove mediante aparências uma consciência, é para o ser da consciência mesma (no mais amplo sentido de corrente de vivências) necessário ${ }^{41}$.

\subsection{A Fenomenologia como Idealismo Transcendental}

A aproximação da fenomenologia transcendental com o idealismo, sugerida pelo texto das Ideias, viria a se confirmar nas Meditações Cartesianas, onde a fenomenologia pura se apresenta definitivamente como uma forma de idealismo transcendental.

\footnotetext{
${ }^{38}$ HUSSERL, Edmund. Meditações Cartesianas. Introdução à Fenomenologia. Porto: Rés, 2001, p. 34.

${ }^{39}$ HUSSERL, Edmund. Meditações Cartesianas. Introdução à Fenomenologia. Porto: Rés, 2001, p. 34.

${ }^{40}$ Estes são os títulos dos $\S 44$ e $\S 46$ das Ideias.

${ }^{41}$ HUSSERL, Edmund. Ideas Relativas a una Fenomenología Pura y una Filosofía Fenomenológica. Libro Primero: Introduccción general a la fenomenologia pura. México, D.F.: Fondo de Cultura Econômica, 1986, p. 112113.
}

\begin{tabular}{|l|c|l|l|c|c|}
\hline intuitio & $\begin{array}{c}\text { ISSN } \\
1983-4012\end{array}$ & Porto Alegre & Vol.10- $\mathrm{N}^{\mathrm{o} .2}$ & $\begin{array}{c}\text { Dezembro } \\
2017\end{array}$ & p. 21-51 \\
\hline
\end{tabular}


A Correlação entre a Noção de Subjetividade e o Desenvolvimento do Programa da Fenomenologia em Husserl

Para Husserl todo sentido e todo ser imagináveis fazem parte do domínio da subjetividade transcendental, portanto se constituem no interior do ego. Isto significa então que "uma verdadeira teoria do conhecimento só pode ter sentido enquanto fenomenológica e transcendental" ${ }^{42}$ e fundada numa explicitação do ego por si próprio. Esta explicitação é, em primeiro lugar, uma explicitação de si próprio que pretende mostrar de forma sistemática "como é que o ego se constitui a si próprio como existência em si da sua essência própria" e, em segundo lugar, uma explicitação de si próprio, em sentido lato, "que mostra como é que o ego constitui em si os 'outros', a 'objetividade' e, em geral, tudo aquilo que para o $e g o$ - seja no eu ou no não-eu - possui um valor existencial" ${ }^{43}$. Assim Husserl afirma que:

Realizada desta maneira sistemática e concreta, a fenomenologia é, por isso mesmo, idealismo transcendental, ainda que num sentido fundamentalmente novo. Não o é no sentido de um idealismo psicológico que, a partir dos dados sensíveis desprovidos de sentido, quer deduzir um mundo pleno de sentido. Não é um idealismo kantiano que crê poder deixar aberta a possibilidade de um mundo de coisas em si, ainda que a título de conceito-limite. É um idealismo que não é nada mais do que uma explicitação do meu ego enquanto sujeito de conhecimentos possíveis. Uma explicitação consequente, realizada sob a forma de ciência egológica sistemática, dando conta de todos os sentidos existenciais possíveis para mim, como ego. Este idealismo não é formado através de um jogo de argumentos e não se opõe numa luta dialética a qualquer 'realismo'. É a explicitação do sentido de qualquer tipo de ser que eu, ego, posso imaginar; e, mais especificamente, do sentido da transcendência que a experiência me dá realmente: a da Natureza, da Cultura, do Mundo, em geral; o que quer dizer o seguinte: desvendar de uma maneira sistemática a própria intencionalidade constituinte. A prova deste idealismo é a própria fenomenologia ${ }^{44}$.

O idealismo transcendental da fenomenologia pura é portanto a explicitação correta do caminho que conduz, através da redução, do terreno da atitude natural ao ego transcendental. Isto se verifica de tal forma em Husserl que o próprio autor afirma que "só quem compreendeu mal o sentido profundo do método intencional ou o sentido da redução transcendental - ou um e outro - pode querer separar a fenomenologia e o idealismo transcendental"45.

O Ego transcendental é o principal resultado da operação de redução transcendental e consequentemente, segundo o próprio Husserl afirma, aquilo que conduz a fenomenologia ao idealismo transcendental. Paralelamente, este idealismo é a explicitação do ego cogito como "sujeito de conhecimentos possíveis". A fenomenologia deve espelhar o caráter necessário da filosofia como “filosofia fenomenológica transcendental”, “[...] e, correlativamente, no que concerne ao universo daquilo

${ }^{42}$ HUSSERL, Edmund. Ideas Relativas a una Fenomenología Pura y una Filosofía Fenomenológica. Libro Primero: Introduccción general a la fenomenologia pura. México, D.F.: Fondo de Cultura Econômica, 1986, p. 111. ${ }^{43}$ Ibid., p. 111.

${ }^{44}$ HUSSERL, Edmund. Ideas Relativas a una Fenomenología Pura y una Filosofía Fenomenológica. Libro Primero: Introduccción general a la fenomenologia pura. México, D.F.: Fondo de Cultura Econômica, 1986, p. 111112.

${ }^{45}$ Ibid., p. 112.

\begin{tabular}{|l|c|l|l|c|c|}
\hline intuitio & $\begin{array}{c}\text { ISSN } \\
1983-4012\end{array}$ & Porto Alegre & Vol.10- $\mathrm{N}^{\mathrm{o} .2}$ & $\begin{array}{c}\text { Dezembro } \\
2017\end{array}$ & p. 21-51 \\
\hline
\end{tabular}


A Correlação entre a Noção de Subjetividade e o Desenvolvimento do Programa da Fenomenologia em Husserl

que é real e possível para nós, o 'estilo' da interpretação, a única possível, do seu sentido, a saber, o idealismo fenomenológico transcendental" 46 .

O campo da consciência transcendental, da consciência pura, é uma esfera absoluta que não necessita senão dela para existir.

\section{A fenomenologia constitutiva e o mundo da vida}

Recapitulando brevemente o caminho percorrido até aqui, partimos de uma explicação inicial dos princípios constituintes da fenomenologia, constatamos seu vínculo com o tema do sujeito e mesmo com uma teoria da subjetividade ali implícita para em seguida, a partir dessa proximidade, descrever a transformação da fenomenologia inicial em uma metodologia investigativa dos fenômenos de cunho transcendental, através do paralelismo apresentado com a discussão do desenvolvimento do tema relativo ao problema do Eu puro e do Ego transcendental.

Ora bem, a constatação de que o Ego transcendental é por fim o que resta como resíduo da operação de "aniquilação do mundo", enquanto posição real de um objeto existente fora da minha consciência transcendental constituinte, é algo já posto programaticamente no volume primeiro das Ideias em 1913. Podemos inclusive assinalar que o ressurgimento do Eu puro nas Ideias é marcadamente um dos pontos nodais no qual Husserl se vê obrigado a obrigado a recuar das análises contidas nas Investigações, motivado, como mostrado acima, pela necessidade metódica de uma esfera transcendental que escape do campo fenomênico da psicologia fenomenológica, do Eu empírico, psíquico e psicofísico, caso as descrições fenomenológicas queiram, por fim, se impor através de uma metodologia pura.

No entanto, precisamente nesse ponto, há algo que não foi tido antes nas nossas análises sobre o Eu puro nas Ideias, mais exatamente sobre o projeto mesmo da fenomenologia assinalado naquele texto. Além de marcar a "virada transcendental" da fenomenologia ali também se pretende estabelecer, a partir de um programa, as etapas subsequentes de investigação através da qual a fenomenologia poderia se estabelecer de pleno direito como uma espécie de propedêutica a toda investigação filosófica e científica rigorosamente fundada.

A exigência de uma fundamentação a priori da fenomenologia pura e o idealismo transcendental fenomenológico como seu último estágio tem nesse sentido uma razão de ser. Paradoxalmente, $o$ idealismo fenomenológico se converte em um empirismo radical, porque o colocar "entre parênteses" a

46 HUSSERL, Edmund. Ideas Relativas a una Fenomenología Pura y una Filosofía Fenomenológica. Libro Primero: Introduccción general a la fenomenologia pura. México, D.F.: Fondo de Cultura Econômica, 1986, p. 112.

\begin{tabular}{|l|c|c|c|c|c|}
\hline intuitio & $\begin{array}{c}\text { ISSN } \\
1983-4012\end{array}$ & Porto Alegre & Vol.10- No.2 & $\begin{array}{c}\text { Dezembro } \\
2017\end{array}$ & p. 21-51 \\
\hline
\end{tabular}


A Correlação entre a Noção de Subjetividade e o Desenvolvimento do Programa da Fenomenologia em Husserl

tese do mundo natural só tem razão de ser se metodologicamente significa um retorno "às coisas mesmas" através da purificação transcendental da experiência.

Assim, chegando neste ponto do trabalho cumpre, por fim, mencionar um tema considerado tardio na fenomenologia inicial mas cuja temática podemos reconhecer já a partir do segundo volume das Ideias (publicado postumamente), dedicado aos problemas constitutivos da fenomenologia, trata-se do retorno ao solo do "pré-dado" no mundo vivido, ou como aparece nas obras finais de Husserl, dos problemas genéticos da fenomenologia, do "mundo da vida".

\subsection{A constituição da Natureza e do espírito}

Como vimos anteriormente, com a edição do primeiro volume das Ideias em 1913 temos não apenas o marco da virada transcendental da fenomenologia mas também o anúncio de um programa a ser cumprido em etapas subsequentes de investigação. Por esse motivo, o volume em questão leva o subtítulo de Introdução geral à fenomenologia pura, tratando-se assim da apresentação das linhas gerais do programa futuro da fenomenologia e da investigação fenomenológica fundamental que nos colocaria de posse do campo reduzido da consciência pura, o campo de atuação propriamente tido de toda fenomenologia transcendental.

O projetado segundo volume das Ideias trata das Investigações sobre a constituição e tem a função de mostrar como se constituem fenomenologicamente os estratos de sentido da natureza material, do mundo anímico e do mundo do espírito, fundados uns sobre os outros, passando assim dos níveis mais baixos aos níveis constitutivos superiores.

Com vistas ao objetivo e aos limites desse trabalho não nos deteremos nas análises constitutivas da natureza material, contudo, retemos de início aquilo que para os nossos propósitos é o seu resultado mais significativo: a dependência da experiência da coisa material com relação ao corpo subjetivo. Além disto, veremos que ao cabo deste trabalho uma outra apreensão da experiência do corpo próprio voltará a ter um papel central para os objetivos aqui propostos.

Assim, a apreensão do complexo de sensações que tem lugar na natureza material que compõe o nosso mundo circundante tem por referência perceptiva o corpo. De pronto se compreende que é através dele que "se põe de manifesto que a constituição das coisas materiais como aistheta, tal como se encontram ante mim intuitivamente, são dependentes de minha constituição, a do sujeito experimentante, referida a meu corpo e minha 'sensibilidade normal"." E isto porque, "o corpo é, antes de tudo, o meio de

\begin{tabular}{|l|c|l|l|c|c|}
\hline intuitio & $\begin{array}{c}\text { ISSN } \\
1983-4012\end{array}$ & Porto Alegre & Vol.10- $\mathrm{N}^{\mathrm{o} .2}$ & $\begin{array}{c}\text { Dezembro } \\
2017\end{array}$ & p. 21-51 \\
\hline
\end{tabular}


A Correlação entre a Noção de Subjetividade e o Desenvolvimento do Programa da Fenomenologia em Husserl

toda a percepção; é o órgão da percepção; envolvido necessariamente em toda percepção ${ }^{47}$. Como tal, tudo o que diz respeito a sensação no sentido geral em que pode ser experienciado, "todo a coisa-real do mundo circundante", encontra nele seu fundamento.

E patente também está em conexão com ele o característico que faz do corpo o portador do ponto de orientação zero ${ }^{*}$, do aqui e agora, desde o qual o eu puro intui o espaço e o mundo inteiro dos sentidos. Assim, toda coisa que aparece tem portanto, eo ipso, uma referência de orientação ao corpo, e não somente a coisa realmente aparente, senão toda coisa que há de poder aparecer ${ }^{48}$.

Assim, o corpo é já em um primeiro momento o ponto de orientação e referência sensorial a partir do qual todo dado no meu mundo circundante se constitui, precisamente, em meu entorno. Mas, para além disso, o que se diz do corpo estético como referência para a constituição da experiência da natureza material pode se estende para outros níveis. A passagem da constituição da natureza material à da natureza humana, na qual se inclui a "alma humana ou animal", tem de se dar tendo por base a vinculação ainda, precisamente, com um "corpo material". É desse modo que quando consideramos o homem como natureza, e isso quer dizer aqui como realidade anímica, o "ser animal", temos por base o corpo material referido a natureza, sobre o qual então se constituem os novos estratos "anímicos-corporais".

Contudo, não se perde de vista aqui que a referência a qual estas investigações seriam possíveis continua sendo o Ego puro obtido metodologicamente no primeiro volume da Ideias. Assim, ao fazermos a passagem ao problema da constituição da natureza animal, na qual entra portanto a constituição do homem natural, trata-se do ponto de vista do Ego constitutivo de se compreender como "objeto natural". Ou seja, mantém-se o paralelismo visto anteriormente que faz do eu empírico, o "Ego real", o correlato transcendente constituído, cujo significado é dado graças a correlação com o Ego puro imanente da consciência transcendental.

Assim, na passagem à discussão da natureza humana importa em primeiro lugar a referência a unidade pressuposta do Eu puro transcendental, o seu correlato, o eu anímico real, por outro lado, é a contraparte "[...] onde a alma está constituída como uma realidade enlaçada com a realidade do corpo ou entrelaçada nela" ${ }^{\text {49 }}$. É assim que como correlato do mundo material, se constitui uma subjetividade que não é nem inteiramente corpo subjetivo nem coisa material.

47 HUSSERL, Edmund. Ideas Relativas a una Fenomenología Pura y una Filosofía Fenomenológica. Libro Segundo: Investigaciones fenomenológicas sobre la constitución. México, D.F.: Fondo de Cultura Econômica, 2005, p. 88.

* Grifos nossos: Assinalamos aqui a noção do corpo como espécie de grau zero da experiência do mundo circundante ao qual retornaremos na última parte desse trabalho para mostrar como, dentro de outros marcos metodológicos, ele pode ser visto como síntese da relação entre consciência e mundo.

${ }^{48}$ Ibid., p. 88.

${ }^{49}$ Op.cit., p. 127.

\begin{tabular}{|l|c|c|c|c|c|}
\hline intuitio & $\begin{array}{c}\text { ISSN } \\
1983-4012\end{array}$ & Porto Alegre & Vol.10- No.2 & $\begin{array}{c}\text { Dezembro } \\
2017\end{array}$ & p. 21-51 \\
\hline
\end{tabular}


A Correlação entre a Noção de Subjetividade e o Desenvolvimento do Programa da Fenomenologia em Husserl

Há, portanto, uma diferença na relação com os objetos em geral e na relação que tenho com meu próprio corpo, quando, por exemplo, tateio a minha mão esquerda ${ }^{50}$. Em primeiro lugar tenho com isto a experiência da coisa "mão esquerda" que pertence objetivamente a mão direita, mas também sensações pertencentes a ela que não entram na descrição da coisa física, pois aí a coisa tocada se volta também como corpo sensiente. Assim também como a mão que toca pode voltar-se em corpo estranho, coisa que toca. Vê-se a diferença: se a mão toca ou é tocada por um corpo estranho, então temos a sensação localizda da mão sendo tocada, quando, porém, isto ocorre com outras partes do corpo temos uma duplicação da experiência, pois cada parte é então por sua vez "corpo" e "coisa externa" que toca. Explica-se assim que a corporeidade pode ser vista tanto do lado material quanto da sensação, e isto porque

O corpo, portanto, se constitui originalmente de maneira dupla: por um lado é coisa física, matéria, tem sua extensão, na qual ingressam suas propriedades reais, a coloração, lisura, dureza, calor, e quantas outras propriedades materiais similares aja; por outro lado, encontro nele, e sinto "nele" e "dentro" dele: o calor no dorso da mão, o frio nos pés, as sensações de toque nas pontas dos dedos ${ }^{51}$.

O corpo não é portanto apenas um objeto físico mas também suporte de todo complexo de sensações que remetem à natureza material e ao mundo anímico, "desta maneira, pois, a consciência total de um homem está enraizada em certa maneira com seu corpo mediante seu suporte hylético [...]" (p.193). Embora as vivências intencionais propriamente ditas, quer dizer, "o perceber", "o pensar" apreendidas na intuição, não possuam uma localização corporal, nem formam nele um estrato - pois não são conteúdos de sensação que pudéssemos referir ao corpo -, por outro lado, “[...] correlativamente ao mundo material, se constitui um sujeito de capacidades corporais-anímicas (de faculdades sensoriais, faculdades de movimento livre, de apercepção, etc.), em que o corpo se apresenta tanto como corpo e como coisa material" ${ }^{\prime 52}$.

Assim também se explica o que é dito acima sobre o corpo como centro de orientação, pois $a$ cada eu corresponde um certo "domínio perceptivo" que, precisamente, se mantém como referencial no qual as coisas são percebidas. Se as coisas enquanto seres espaciais têm esse sentido de estarem orientadas, em referência ou direção a algo, o corpo tem para o eu a peculiaridade de ser o ponto zero de todas as orientações. Todas as suas partes são dadas “aqui", não me é possível referi-las "ali" no modo de um ponto de vista de fora. "Assim, todas as coisas do mundo circundante possuem sua orientação

\footnotetext{
${ }^{50}$ Exemplo paradigmático que terá importância fundamental para as análises da corporeidade por Merleau-Ponty.

${ }^{51}$ HUSSERL, Edmund. Ideas Relativas a una Fenomenología Pura y una Filosofía Fenomenológica. Libro Segundo: Investigaciones fenomenológicas sobre la constitución. México, D.F.: Fondo de Cultura Econômica, 2005, p. 185.

${ }^{52}$ Ibid., p. 197.
}

\begin{tabular}{|c|c|l|l|c|c|}
\hline 1 intuitio & $\begin{array}{c}\text { ISSN } \\
1983-4012\end{array}$ & Porto Alegre & Vol.10- $\mathrm{N}^{\circ} .2$ & $\begin{array}{c}\text { Dezembro } \\
2017\end{array}$ & p. 21-51 \\
\hline
\end{tabular}


A Correlação entre a Noção de Subjetividade e o Desenvolvimento do Programa da Fenomenologia em Husserl

relativamente ao corpo, tal como todas as expressões da orientação levam consigo esta referência",53, porque o "corpo do sujeito" não é um ponto fixo, pode alterar livremente seu lugar no espaço e, ao fazer isso, alterar assim também a orientação das coisas ao seu entorno.

Podemos então assim dizer que "[...] eu tenho todas as coisas frente a mim, todas estão 'ali' com exceção de uma única, precisamente o corpo, que sempre está 'aqui'",54. A localização desse eu e seu corpo é sempre mutável, porém cada lugar em que se encontre permanece sempre o centro em torno do qual se organiza o seu mundo circundante.

Mas se é assim, com base nessas descrições, podemos dizer que formaria o tema da corporeidade (como veremos, tão caro à fenomenologia francesa ${ }^{55}$ ), com sua peculiaridade, um ponto nodal de uma esfera de problemas próprios?

No entanto, cabe lembrar o contexto em que o corpo é apresentado, na passagem da natureza material ao mundo animal e posteriormente ao mundo do espírito, ele serve como espécie de ancoragem, base material sobre a qual se constitui sucessivamente os estratos superiores de significação mantendo como referência a base sensível do mundo circundante. Mas, justamente, a esfera do corpo não forma por si só um campo de investigação independente. Como se verá em seguida, a sua significação e tudo que se inclui como natureza só tem sentido por referência ao espírito.

Quer dizer, a análise da natureza mostra que ela necessita de um "complemento", qual seja, da subjetividade com seus pressupostos, que, embora também se possam referir ao anímico e ao natural, não são por si só natureza mas um outro "setor" do ser. Resulta isto na oposição entre as esferas do mundo naturalista e personalista. A partir do momento em que se passa aos problemas constitutivos do mundo do espírito, compreende-se também que a modificação da posição personalista, os estratos da experiência do meu mundo sensível circundante natural são agora correlatos do eu em atitude transcendental, ou seja, tem por referência a pessoa.

Ao passarmos a análise da constituição do mundo espiritual temos não apenas uma modificação mas mesmo uma oposição entre natureza e espírito. De um ponto de vista metodológico essa oposição corresponde, entre outras coisas, a distinção geral entre o método das ciências da natureza e das ciências

${ }^{53}$ HUSSERL, Edmund. Ideas Relativas a una Fenomenología Pura y una Filosofía Fenomenológica. Libro Segundo: Investigaciones fenomenológicas sobre la constitución. México, D.F.: Fondo de Cultura Econômica, 2005, p. 198.

${ }^{54}$ Ibid., p. 198-199.

${ }^{55}$ Conforme lembra Paul Ricoeur nas suas análises das Ideias II, tal não parece ser o caso para Husserl, uma vez que estas investigações se encontram ainda distantes do que veremos a seguir na apropriação dessa temática pela fenomenologia francesa, pois "não se trata, em Ideen II, de encontrar um tipo de presença do mundo, cujas significações seriam projetadas pelo desenvolvimento de nosso poderes corporais, aquém das relações de nível intelectual e científico". De modo que, "deve-se observar que o corpo que aparece assim não é aquilo que os autores franceses, seguindo G. Marcel, chamaram de corpo próprio, mas já uma quase realidade psicofisiológica. Na verdade, a preocupação de Husserl nas Ideen II não consistirá nunca em opor 'existência' e 'objetividade', mas seguir ao contrário o progresso da objetivação, não tendo como fundo algo 'existencial', mas tomando como fundo algo 'transcendental'” (RICOEUR, 2009, pp. 98-99; p. 104).

\begin{tabular}{|l|c|l|l|c|c|}
\hline intuitio & $\begin{array}{c}\text { ISSN } \\
1983-4012\end{array}$ & Porto Alegre & Vol.10- $\mathrm{N}^{\mathrm{o} .2}$ & $\begin{array}{c}\text { Dezembro } \\
2017\end{array}$ & p. 21-51 \\
\hline
\end{tabular}


A Correlação entre a Noção de Subjetividade e o Desenvolvimento do Programa da Fenomenologia em Husserl

do espírito, o que para as investigações constitutivas da fenomenologia correspondem a de um lado o aspecto descritivo da natureza material e anímica e de outro o aspecto personalista do ego constituinte.

Mas, justamente, em que consiste a atitude personalista? Ora, mesmo na análise fenomenológica da atitude naturalista, ao fazermos dela tema de reflexão e, portanto das sucessivas reduções fenomenológicas que nos revelam aos estratos constituídos sobre a base originária não tematizada do mundo circundante no qual sempre nos movemos, retemos dela seu eidos e pomo-nos em terreno de investigações "puramente fenomenológicas", e é como sujeito dessa atitude que referimos então o eu puro. Nisto também se inclui o eu empírico e tudo quanto faça parte do seu mundo circundante.

Lembremos que a passagem à atitude transcendental própria do eu puro constituinte conserva todo o sentido da atitude naturalística, mas, ao mesmo tempo, há uma modificação no seu modo de apreensão. Tendo isso em vista, assinala-se aqui em que medida o método tem importância fundamental na mudança de atitude da investigação fenomenológica. Metodologicamente essa "atitude nova" pode ser dita " "não natural': isto quer dizer que o experimentado nela não é natureza no sentido de todas as ciências da natureza, senão por assim dizer uma contraparte da natureza" ${ }^{96}$. Ou seja, a operação artificial na qual consiste a redução à consciência pura se afirma mediante a necessidade de evitar a constante sobreposição entre as atitudes naturalista a personalista, ou seja, evitar assim a confusão entre aquilo que no fenômeno é meramente relativo a objetividades e o que se apreende em sentido absoluto como essência.

Desta maneira, assim como pudemos antes falar do corpo como centro de orientação considerado na minha atitude naturalística, agora, em atitude personalista, a pessoa é então o ponto central do mundo circundante. E isto porque aqui o mundo circundante não é de pronto a realidade física tal como se apresenta, mas, apenas, na medida em que é captada e posicionada com esse sentido por uma subjetividade pessoal.

Dito com toda generalidade, o mundo circundante não é um mundo "em si", senão mundo "para mim", precisamente mundo circundante do seu sujeito-eu, mundo experimentado por ele, ou consciente de algum outro modo, posto em suas vivências intencionais com um respectivo conteúdo de sentido ${ }^{57}$.

Se podemos falar do mundo sensível como um núcleo de experiências, a ele o eu faz referência em atos novos ou fundados sobre aqueles mas que, justamente, só tem sentido por referência ao eu. É desse modo também que se pode compreender o sentido das experiências que tem lugar na esfera da pessoalidade, aquelas que agora fazem parte da comunidade de pessoas desse "mundo circundante comum", e tudo o mais que pertencem no mundo do espírito. Ao adentrarmos o campo da personalidade e seu mundo circundante temos uma atitude distinta da naturalista e do seu modo de proceder investigativo.

56 HUSSERL, Edmund. Ideas Relativas a una Fenomenología Pura y una Filosofía Fenomenológica. Libro Segundo: Investigaciones fenomenológicas sobre la constitución. México, D.F.: Fondo de Cultura Econômica, 2005, p. 225 .

${ }^{57}$ Ibid., p. 232.

\begin{tabular}{|l|c|c|c|c|c|}
\hline intuitio & $\begin{array}{c}\text { ISSN } \\
1983-4012\end{array}$ & Porto Alegre & Vol.10 - No.2 & $\begin{array}{c}\text { Dezembro } \\
2017\end{array}$ & p. 21-51 \\
\hline
\end{tabular}


A Correlação entre a Noção de Subjetividade e o Desenvolvimento do Programa da Fenomenologia em Husserl

E então há que se perguntar em que consiste essa contraposição,

"se trata realmente de dois mundos, da 'natureza' por um lado, do mundo do espirito por outro, separados ambos por diferenças cardinais de ser?" Com efeito, não parece ser o caso "[...] que ambos mundos não tem nada que ver um como o outro, que seus sentidos não estabelecem referências essenciais entre eles", senão que se trata antes de "diferenças cardinais de 'atitude", de modo que é sempre possível uma mediação tendo em conta a referência de sentido: "[...] as coisas como aparições são precisamente aparições das coisas da física, a consciência pura é constituinte para estas ou aquelas unidades constituídas, e assim sucessivamente" $"$.

Por isso também, a mudança cardinal de atitude que se opera com a passagem à perspectiva personalista do mundo do espírito oferece a possibilidade de compreensão naturalística, pois esta é incorporada como estrato à vida espiritual. O corpo no qual adivinhamos a atividade do espírito assim nos aparece porque, precisamente, conservamos como estrato esse fragmento de natureza anímica. "A unidade do corpo e do espírito é uma unidade dupla, e correlativamente na apercepção unitária do homem está incluída uma dupla apreensão (a personalista e a naturalista)" ${ }^{, 59}$.

Nessa medida se pode dizer que para compreender um homem é necessário descer ao "subsolo" no qual se "edifica" sua vida espiritual.

Assim, pois, se tomamos agora ao eu pessoal no nexo de seu desenvolvimento, então encontramos dois níveis que eventualmente podem separar-se (por exemplo, o nível inferior como animalidade "pura"), uma dupla "subjetividade": a superior é a especificamente espiritual, o estrato do intellectus agens, do eu livre como eu dos atos livres, entre eles todos os atos de razão propriamente ditos, os atos positiva, mas também os negativamente racionais. Logo a este nível pertence também o eu não livre, entendida a não-liberdade no sentido em que vigora precisamente para um eu real: eu me deixo arrastar pela sensibilidade. Este eu especificamente espiritual, o sujeito dos atos do espírito, a personalidade, se encontra ele mesmo dependente de um subsolo obscuro de predisposições de caráter, disposições originárias e latentes, e por outro lado dependente da natureza ${ }^{60}$.

É assim que, se todo vivenciar é vivenciar de um eu, o nexo de vivências que pertencem ao homem remete a esse subsolo constantemente enriquecido do pré-dado. E isto é assim porque o "mundo de coisas" no qual vivem os espíritos é aquele constituído como objetivo para essas subjetividades, quer dizer, o "mundo circundante dos espíritos objetivamente determinável". Ou seja, nesse sentido, "todo espírito tem um 'lado de natureza",61. Ele é esse subsolo da subjetividade que formam a base sensações sobre as quais se constituem as camadas de estratos superiores da vida anímica e do eu empírico real. É dessa forma que os espíritos, aqueles que executam cogitationes, que efetivamente tomam posição e são

${ }^{58}$ HUSSERL, Edmund. Ideas Relativas a una Fenomenología Pura y una Filosofía Fenomenológica. Libro Segundo: Investigaciones fenomenológicas sobre la constitución. México, D.F.: Fondo de Cultura Econômica, 2005, p. 257, grifos nossos.

${ }^{59}$ Ibid., p. 294-295.

${ }^{60}$ Op.cit., p. 324.

${ }^{61}$ HUSSERL, Edmund. Ideas Relativas a una Fenomenología Pura y una Filosofía Fenomenológica. Libro Segundo: Investigaciones fenomenológicas sobre la constitución. México, D.F.: Fondo de Cultura Econômica, 2005, p. 327.

\begin{tabular}{|l|c|l|l|c|c|}
\hline intuitio & $\begin{array}{c}\text { ISSN } \\
1983-4012\end{array}$ & Porto Alegre & Vol.10- $\mathrm{N}^{\mathrm{o} .2}$ & $\begin{array}{c}\text { Dezembro } \\
2017\end{array}$ & p. 21-51 \\
\hline
\end{tabular}


A Correlação entre a Noção de Subjetividade e o Desenvolvimento do Programa da Fenomenologia em Husserl

capazes de motivações racionais, podem se referir e mesmo se reconhecer como natureza. Porque o espírito não é apenas um eu abstrato, mas uma "personalidade plena", é que "a mim me co-pertence um subsolo de vivências e um subsolo de natureza ('minha natureza') que se manifesta na engrenagem das vivências" $"$.

Porém, se o subsolo do espírito se mostra como lado de natureza, a co-pertença da esfera natural, ao cabo, cabe, no entanto, ao mundo espiritual a "primazia ontológica" frente ao mundo naturalista. Portanto, se o espírito pode ser descrito como dependente da natureza, e até certo ponto naturalizado, isto só pode ser verdadeiro até determinado grau, pois "os sujeitos não podem dissolver-se no ser natureza, já que então faltaria o que dá sentido à natureza" ${ }^{33}$. Assim, a relação de dependência entre espírito e natureza não é simétrica. Frente a esta, o espírito conserva um absoluto irrelativo de uma ordem própria, que consiste na prerrogativa de que em se suprimindo o espírito nada de sentido resta do lado da natureza, porém, se, de outro modo, suprimimos a natureza resta ainda do lado do espírito um eu com sua vida de consciência e nela uma individualidade capaz de "julgar", "valorar", e tomar posição frente aos atos próprios desta esfera.

Disso se compreende que "nenhuma coisa tenha em si mesma sua individualidade", mas apenas o espírito, quer dizer, "individuação absoluta a tem já o eu puro da cogitatio respectiva, a qual é ela mesma algo em si absolutamente individual" ${ }^{\prime 64}$. Porque se é a consciência a única que efetivamente se pode assinalar na sua essência, então toda "coisidade objetiva" se determina, e tem sua unidade e individualidade, por referência a esse absoluto.

Toda individualidade recebe portanto sua determinação por referência a alguma subjetividade ou complexo de sujeitos, ou seja, "o único originariamente individual é a consciência concreta com seu eu. Todo outro individual é algo aparente e tem o princípio de sua individuação no aparecer real e possível, que por seu lado remete a uma consciência individual"65. A "individuação absoluta" é então algo que pertence ao eu pessoal, pois o que podemos referir como o "mundo circundante do eu" só encontra sua plena individuação, justamente, porque tem como referência o eu e através dele a experiência comum outros indivíduos.

O problema da individuação referido a esfera ampla dos problemas constitutivos da fenomenologia transcendental apresenta um ganho no tratamento dos elementos próprios da subjetividade quando comparado ao aspecto formal apresentado nas Ideias I. Contudo, como não poderia deixar de ser,

62 HUSSERL, Edmund. Ideas Relativas a una Fenomenología Pura y una Filosofía Fenomenológica. Libro Segundo: Investigaciones fenomenológicas sobre la constitución. México, D.F.: Fondo de Cultura Econômica, 2005, p. 328.

${ }^{63}$ Ibid., p. 346.

${ }^{64}$ Op.cit., p. 348.

65 HUSSERL, Edmund. Ideas Relativas a una Fenomenología Pura y una Filosofía Fenomenológica. Libro Segundo: Investigaciones fenomenológicas sobre la constitución. México, D.F.: Fondo de Cultura Econômica, 2005, p. 350, grifos nossos.

\begin{tabular}{|c|c|l|l|c|c|}
\hline intuitio & $\begin{array}{c}\text { ISSN } \\
1983-4012\end{array}$ & Porto Alegre & Vol.10- $\mathrm{N}^{\circ} .2$ & $\begin{array}{c}\text { Dezembro } \\
2017\end{array}$ & p. 21-51 \\
\hline
\end{tabular}


A Correlação entre a Noção de Subjetividade e o Desenvolvimento do Programa da Fenomenologia em Husserl

em última análise os problemas constitutivos remetem a esfera do ego transcendental como correlatos, e isso quer dizer que toda individuação nas esferas constitutivas da natureza, na qual se reconhece sua base, só pode ser dita dessa forma por referência à consciência pura e à subjetividade transcendental constituinte.

O mundo vivido do qual tomamos parte e do qual emerge a subjetividade é ainda objeto de uma correlação transcendental. Mas seria possível algo como um outro tipo de epoché que abordasse tais problemáticas a partir da perspectiva própria desse mundo da vida? Como fechamento dessa primeira parte do trabalho, traremos dessa outra via para redução, diferente da via cartesiana, que se apresenta assim como um novo recomeço para a fenomenologia.

\subsection{O retorno ao mundo vivido}

A partir inicialmente do diagnóstico da "crise" da humanidade europeia, que do ponto de vista da fenomenologia transcendental é consequentemente a crise da racionalidade, das ciências e da própria filosofia, um exame dos supostos equívocos da filosofia moderna revela por parte da fenomenologia a possibilidade de reconsiderar aquilo que naquela, embora suposto nas análises, se passa por sobre como fenômeno: o próprio mundo vivido enquanto tema de uma investigação própria. É assim que no texto tardio de A crise das ciências europeias e a fenomenologia transcendental (1936) essa questão surge como "questão retrospectiva" (Rückfrage) do "mundo da vida" (Lebenswelt).

O problema aqui posto pode ser entendido em um duplo sentido, de um lado poderia se tratar de uma possibilidade de renovação da investigação fenomenológica que acaba se enredando com uma série de problemas derivados do seu idealismo transcendental sui generis, por outro lado justamente uma reafirmação da necessidade e do consequente desfecho ideal de toda investigação séria e rigorosa que se pretenda, precisamente, na filiação da Ideia de ciência europeia ameaçada pela "crise". Em certo sentido podemos dizer que ambas as posições podem estar corretas.

Se trataria antes de tudo de mostrar que os pressupostos sobre os quais a filosofia moderna em geral assenta a ideia de filosofia e ciência, - compartilhada, como mostramos, pelo projeto da fenomenologia transcendental ao menos no seu espírito -, são tomados de antemão como uma evidência objetiva, portanto, nunca questionado. O "solo inquestionado" sobre o qual a crítica moderna estabelece as condições de possibilidade do conhecimento é o mundo da vida circundante, e é esse "pré-dado" que agora se trata de tomar como "questão retrospectiva".

O pré-dado se encontra na base da nossa experiência cotidiana, e nesse sentido é partilhada então tanto pelo homem comum quanto pelo homem de ciência quando não está, precisamente, à fazê-la.

\begin{tabular}{|l|c|l|l|c|c|}
\hline intuitio & $\begin{array}{c}\text { ISSN } \\
1983-4012\end{array}$ & Porto Alegre & Vol.10- $\mathrm{N}^{\mathrm{o} .2}$ & $\begin{array}{c}\text { Dezembro } \\
2017\end{array}$ & p. 21-51 \\
\hline
\end{tabular}


A Correlação entre a Noção de Subjetividade e o Desenvolvimento do Programa da Fenomenologia em Husserl

Tendo isto presente, um esclarecimento explícito da validade objetiva e de toda a tarefa da ciência exige manifestamente que se comece por indagar acerca do mundo pré-dado. Este é naturalmente dado a todos nós, como pessoas no horizonte da nossa cohumanidade, ou seja, em cada conexão real [Aktuellen] com o outro, pré-dado com "o" mundo, o universal comum ${ }^{66}$.

Tanto para o homem cotidiano como para o cientista esse mesmo solo se apresenta como fundo de toda experiência vivida, pois "[...] faz todo o sentido para os homens que nele vivem a questão acerca do sentido do ser próprio e constante desse mundo da vida." Isso porque "houve sempre já para a humanidade de antes da ciência um mundo da vida, tal como este também prossegue no seu modo de ser após a ciência”. Considerado nessa perspectiva de um mundo que já está sempre presente aí, "assim, é possível levantar-se o problema do modo de ser do mundo da vida em si e por si [...]"*67, independente de qualquer "conhecimento objetivo-científico" que sobre ele se funda.

Contudo, se à práxis cotidiana e ao homem pré-científico é suficiente este conhecimento dado de antemão pela sua experiência de mundo circundante, o mesmo não pode ser dito daquele que pretende produzir ciência. Embora a originalidade das experiências implicadas no que se chama mundo da vida é necessário, em consonância com o próprio espírito que animam as investigações delas resultantes, que sejam esclarecidas no que nelas há de próprio e que as habituais investigações da ciência objetiva tradicional não conseguem captar. O que significa dizer que o tema parece requer o auxílio de "tarefas científicas diversas", de tal modo que devem assim ser tratadas em conjunto e não apenas sob o predomínio da tarefa lógico-objetiva "por si só". Pois é dessa forma que "nunca se questiona cientificamente a maneira como o mundo da vida funciona em permanência como plano de fundo" e de que modo se pode falar que esse pré-lógico pode ser o fundamento das verdades lógico-teóricas. Não se trata aqui, portanto, de eleger ou substituir uma verdade por outra mais essencial, mas de reconhecer um caráter científico próprio do pré-dado, e compreender que

[...] talvez a cientificidade, que esse mundo da vida, como tal e na sua universalidade exige, seja uma cientificidade específica, justamente não lógica-objetiva, e que, como a cientificidade fundamentadora última, o seu valor não seja de o de uma cientificidade menor, mas superior ${ }^{68}$.

\footnotetext{
${ }^{66}$ HUSSERL, Edmund. A Crise das Ciências Européias e a Fenomenologia Transcendental. Rio de Janeiro: Forense Universitária, 2012, p. 99.

* A delimitação do campo pré-científico do mundo da vida frente a visão eminentemente objetivista das ciências em geral terá grande importância para Merleau-Ponty nas suas investigações sobre a percepção e o mundo sensível. Notemos aqui que tal projeto de "reabilitação da experiência sensível" parece estar em consonância com a opinião de Husserl na medida em que o sensível, enquanto considerado no que diz respeito ao "meramente relativo ao sujeito", sempre foi relegado a pecha de "opinião" não digna de ser converter objetivamente em conhecimento. Disto se compreende porque, em nossos dias, ainda "é certo que o 'meramente' tem para nós, como uma antiga herança, o tom desprezado da $\delta$ ó $\xi \alpha "$ (HUSSERL, 2012, p. 101).

${ }^{67}$ HUSSERL, Edmund. A Crise das Ciências Européias e a Fenomenologia Transcendental. Rio de Janeiro: Forense Universitária, 2012, p. 100, grifos nossos.

${ }^{68}$ HUSSERL, Edmund. A Crise das Ciências Européias e a Fenomenologia Transcendental. Rio de Janeiro: Forense Universitária, 2012, p. 101.
}

\begin{tabular}{|l|c|l|l|c|c|}
\hline intuitio & $\begin{array}{c}\text { ISSN } \\
1983-4012\end{array}$ & Porto Alegre & Vol.10- $\mathrm{N}^{\mathrm{o} .2}$ & $\begin{array}{c}\text { Dezembro } \\
2017\end{array}$ & p. 21-51 \\
\hline
\end{tabular}


A Correlação entre a Noção de Subjetividade e o Desenvolvimento do Programa da Fenomenologia em Husserl

O acesso científico ao mundo da vida, quer dizer, a pergunta sobre a relação entre o pensar científico-objetivo e a intuição, o pensar lógico, físico e matemático das teorias e o intuir e intuído antes no mundo da vida, acaba por se tornar o problema geral da validade de uma ciência universal. O problema inicialmente "parcial" da verdade científica do pré-dado se transmuta no problema filosófico mais "universal" na medida em que a verdade da ciência objetiva se funda nos substratos retirados desse solo comum universal do mundo da vida.

Mas teria com isso a fenomenologia efetuado uma guinada radical na sua tendência egoica descrita acima? Seriam os temas emergentes do mundo da vida independentes da abordagem constitutiva da fenomenologia transcendental?

O certo contudo é que o tipo de redução transcendental que aqui se executa, a redução do mundo ao fenômeno transcendental do mundo e a subjetividade transcendental como seu correlato, conduz ao pré-dado do mundo da vida, diferente do caminho "muito mais curto para a epoché transcendental", a "via cartesiana", que "tem a grande desvantagem de que conduz, é certo, como de um salto ao ego transcendental" ${ }^{\prime 69}$. O recurso à redução não é portanto abandonado mas, pelo contrário, tem um percurso mais longo comparado a via curta cartesiana, enriquecido pela necessidade de explicitar os problemas ausentes naquela.

Outro fator, e esse de grande importância para os propósitos desse trabalho, permanece ele também como peça essencial da análise: o eu como polo de referência. Contudo, o que ocorre aqui é uma ordem diferente daquela que encontramos na análise transcendental constituinte, respectivamente: ego cogitatio - cogitata.

O primeiro é o mundo da vida simplesmente dado e, na verdade, antes do mais tal como se dá, existente segundo a percepção como "normal", simples e ininterrupto na pura certeza do ser (ou seja, isento de dúvida). Com o estabelecimento do novo direcionamento do interesse e, assim, na sua rigorosa epoché, o mundo da vida torna-se uma primeira rubrica, indice, fio condutor intencional para o questionamento retrospectivo das multiplicidades das maneiras de aparição e das suas estruturas intencionais. Uma nova direção do olhar, no segundo estágio da reflexão, conduz ao polo eu e ao que é próprio da sua identidade ${ }^{70}$.

De outro modo, também é concebível uma ontologia própria do mundo da vida, quer dizer, prescindindo da esfera transcendental, na atitude natural anterior a epoché, é possível que o mundo da vida se torne tema de uma ciência própria na qualidade de mundo da experiência.

Contudo, apesar do reconhecimento dessa originalidade do pré-dado e portanto da sua maneira peculiar de apreensão, há que atentar para o fato de que se por um lado "podemos a todo momento

\footnotetext{
${ }^{69}$ HUSSERL, Edmund. A Crise das Ciências Européias e a Fenomenologia Transcendental. Rio de Janeiro: Forense Universitária, 2012, p. 126.

${ }^{70}$ Ibid., p. 140.
}

\begin{tabular}{|c|c|c|c|c|c|}
\hline intuitio & $\begin{array}{c}\text { ISSN } \\
1983-4012\end{array}$ & Porto Alegre & Vol.10- No.2 & $\begin{array}{c}\text { Dezembro } \\
2017\end{array}$ & p. 21-51 \\
\hline
\end{tabular}


A Correlação entre a Noção de Subjetividade e o Desenvolvimento do Programa da Fenomenologia em Husserl

restituir a atitude natural", por outro lado, o sentido de uma tal investigação sobre o mundo da vida só pode se constituir como ciência de valor universal se, os fenômenos do mundo da vida, forem o ponto de partida que servem como "fios condutores transcendentais para as atitudes correlativas de nível superior", pois esse tipo de investigação ainda mantém como condição de sua efetivação a "tarefa universal de pesquisa da redução transcendental"71.

Mantêm-se, portanto, a necessidade da epoché sobre a atitude natural na qual se desenvolve a nossa vida no mundo, para que desse modo se possa então tomar uma "posição sobre ela"; mais uma vez "é-nos interdito qualquer interesse pelo ser, pelo ser efetivo ou pelo não ser do mundo" ${ }^{, 72}$. Diferente da epoché transcendental, a epoché do mundo da vida mantém "os interesses vitais humanos" que naquela, via de regra, são abandonados, mas isto não significa o retorno à experiência ingênua do mundo, senão a manutenção do sentido geral que tem a operação da redução: o mundo vital como horizonte da nossa experiência permanece como solo originário, contudo, dele não nos servimos mais, mas também não o perdemos porque, "na epoché, retornamos, todavia, à subjetividade já dotada de mundo"73.

Ora, mas se é assim, temos agora também ao nível do pré-dado uma aporia que antes se apresentava à reflexão na consciência pura, pois como apreendemos acima com a fenomenologia transcendental, a introdução da operação da epoché promove uma alteração no sentido em que o mundo é agora para mim, quer dizer, torna algo de subjetivo. Mas, se além disso, como vemos aqui, a subjetividade que tenta desse modo dar conta da objetividade do mundo sendo ela própria parte do mundo, anuncia-se assim o seguinte paradoxo:

Como pode uma parte constituinte do mundo, a sua subjetividade humana, constituir o mundo inteiro, a saber, constituí-lo como a sua configuração intencional? Como pode constituir o mundo - uma configuração sempre já formada e que assim prossegue, da conexão universal da subjetividade intencionalmente realizadora - como sua configuração intencional, pela qual eles, os sujeitos realizadores em relação mútua, devem ser somente partes constituintes da realização total? [...] O constituinte sujeito do mundo engole, por assim dizer, o mundo inteiro e, assim, também a si próprio. Que contrassenso! ${ }^{74}$.

Eis então o "paradoxo da subjetividade", a simultaneidade com a qual a consciência fenomenológica tem enfim que lidar: "ser sujeito para o mundo" e "ser objeto no mundo".

No entanto, se a expressão de exclamação parece aqui apropriada para expressar esse estado aporético ao qual a fenomenologia do mundo da vida parece também diligentemente nos encaminhar, por outro lado, tal paradoxo só se formula porque encontra nela sentido e resolução. E isso porque para a

\footnotetext{
${ }^{71}$ HUSSERL, Edmund. A Crise das Ciências Européias e a Fenomenologia Transcendental. Rio de Janeiro: Forense Universitária, 2012, p. 142.

${ }^{72}$ Ibid., p. 143.

${ }^{73}$ Op.cit., p. 144.

${ }^{74}$ HUSSERL, Edmund. A Crise das Ciências Européias e a Fenomenologia Transcendental. Rio de Janeiro: Forense Universitária, 2012, p. 147, grifos nossos.
}

\begin{tabular}{|l|c|c|c|c|c|}
\hline intuitio & $\begin{array}{c}\text { ISSN } \\
1983-4012\end{array}$ & Porto Alegre & Vol.10- No.2 & $\begin{array}{c}\text { Dezembro } \\
2017\end{array}$ & p. 21-51 \\
\hline
\end{tabular}


A Correlação entre a Noção de Subjetividade e o Desenvolvimento do Programa da Fenomenologia em Husserl

fenomenologia, e principalmente para o fenomenólogo também enquanto homem que vive seu mundo, tal condição é uma consequência de um esforço de transformar a "obviedade universal do ser do mundo" em algo compreensível.

Percebemos assim que, longe de ser superado, o problema da subjetividade transcendental permanece nas investigações sobre o mundo da vida. Porque, justamente, a resolução dos paradoxos anteriores só pode se dar ainda a partir da epoché e do recurso a função do ego e da comunidade egoica transcendental na qual se explica o ser constituinte e constituído, de e para o mundo, e se adquire verdadeiramente o sentido de um "mundo para todos".

Ora, para toda e qualquer epoché a "redução ao ego absoluto" permanece essencial, "isto continua a determinar todo o método da fenomenologia transcendental"75. E isso porque para explicar $a$ simultaneidade de ser ego constituinte e parte do mundo constituído

O método exige, então, que o ego questione retrospectivamente, de modo sistemático, a partir do seu fenômeno concreto do mundo e, assim, que se conheça a si mesmo, ego transcendental, na sua concreção, na sistemática de seus estratos constitutivo e das suas fundações de validade indizivelmente entrelaçadas. O ego é dado apoditicamente na ação da epoché, mas como uma "concreção muda". Ela tem de ser trazida à explicitação, à expressão e, na verdade, numa "análise" intencional sistemática, questionando retrospectivamente a partir do fenômeno do mundo. Nesse procedimento sistemático adquire-se, em primeiro lugar, a correlação do mundo $e$ da subjetividade transcendental, objetada na humanidade ${ }^{76}$.

Assim, ao contrário do que se poderia esperar sobre uma investigação do mundo da vida pré-dado, o problema da subjetividade transcendental não é abandonado, nem resolvido. Embora transmutado pela introdução de uma nova epoché, ele ressurge como o paradoxo acima de um sujeito que constitui o mundo e assim também, como parte dele, constitui a si próprio.

Mas seria esse paradoxo da subjetividade algo fortuito? O simultâneo ser sujeito e ser objeto não é ele mesmo uma variante do paradoxo que aparece também à fenomenologia transcendental na sua via cartesiana na figura do ego constituinte e constituído? Por fim, não é a insistência nessa figura do eu puro, do ego transcendental, e ainda aqui no polo eu como substrato último, nunca tematizado, e acompanhante último da consciência, a fonte mesmo desse paradoxo?

\section{Conclusão: a persistência do paradoxo da subjetividade no programa da fenomenologia}

\footnotetext{
${ }^{75}$ HUSSERL, Edmund. A Crise das Ciências Européias e a Fenomenologia Transcendental. Rio de Janeiro: Forense Universitária, 2012, p. 153.

${ }^{76}$ Ibid., p. 153, grifos nossos.
}

\begin{tabular}{|l|c|c|c|c|c|}
\hline intuitio & $\begin{array}{c}\text { ISSN } \\
1983-4012\end{array}$ & Porto Alegre & Vol.10- No.2 & $\begin{array}{c}\text { Dezembro } \\
2017\end{array}$ & p. 21-51 \\
\hline
\end{tabular}


A Correlação entre a Noção de Subjetividade e o Desenvolvimento do Programa da Fenomenologia em Husserl

Embora o objetivo aqui proposto não seja o de dar uma resposta a tais questões, parece, no entanto, que podemos oferecer ao menos algumas indicações sobre o paradoxo que permanece presente nesta análise da correlação entre a noção de subjetividade e o desenvolvimento do projeto da fenomenologia.

Em um primeiro momento parece estar demostrado a estrita ligação entre o problema da subjetividade e o desenvolvimento programático da fenomenologia, a ponto do referido ponto escolhido como fio condutor das análises precedentes, o desenvolvimento da noção de Ego transcendental, representar ao mesmo tempo o resultado, mas também a forma pela qual a reflexão fenomenológica se encaminha na direção de uma reivindicada pureza e rigor próprios da investigação transcendental. Em consequência disso, um resultado de particular importância para a crítica posterior diz respeito a forma como o Eu puro, ausente nas análises descritivas das Investigações Lógicas, é novamente reintroduzido na perspectiva da fenomenologia transcendental como polo de unidade reflexivo das vivências na consciência pura $^{77}$. Ou, mais exatamente, porque o Ego cogito transcendental não é ele mesmo tematizado pela redução mas permanece sempre como condição e resíduo de toda consciência pura? E ainda assim, se se poderia dizer que para a fenomenologia transcendental ele representa o próprio movimento necessário da reflexão, por outro lado, não caberia também indagar que é esse o $\operatorname{ser}^{78}$ da subjetividade transcendental enquanto acompanhante de todo ato intencional?

Como resultado geral dessas análises, resta ainda a pergunta de o porquê do programa geral da fenomenologia se transmuta em idealismo transcendental? Como visto por último na temática do mundo da vida, a fenomenologia permanece de algum modo sempre fiel ao propósito último de retorno aos fenômenos e, no entanto, o retorno parece sempre adiado em nome da necessidade de clarificação do terreno da consciência pura onde se dariam por fim os elementos essenciais da nossa experiência do mundo vivido então transcendentalmente purificados ${ }^{79}$. Assim, embora o empírico, a atitude natural,

\footnotetext{
${ }^{77}$ Remetemos aqui em especial à crítica de Sartre contida em A transcendência do Ego (1936), onde o objetivo é precisamente "[...] mostrar aqui que o Ego não está na consciência nem formal nem materialmente: ele está fora, $n o$ mundo; é um ser do mundo, tal como o Ego de outrem". Do mesmo modo o autor faz notar que Husserl "depois de ter considerado que o Eu [Moi] era uma produção sintética e transcendente da consciência (nas Logische Untersuchungen), retomou, nas Ideen, à tese clássica de um Eu transcendental que estaria como que por detrás de cada consciência [...]" (SARTRE, 1994, p. 43; p. 46-47).

${ }^{78}$ A crítica fenomenológica aos fundamentos da fenomenologia desenvolvida por Heidegger nos Prolegômenos para uma história do conceito de tempo (1925) se apresenta nesta perspectiva, pois aponta na fenomenologia transcendental de Husserl uma falta de tematização do é propriamente a "região da consciência pura", calcada na "omissão" com relação a questão do "ser do intencional", ou "dito de outro modo: quando se diz que a esfera da consciência é uma esfera e uma região de ser absoluto, que significa aqui ser?" (HEIDEGGER, 2006, p. 13).

${ }^{79}$ Nesse sentido Natalie Depraz se refere a metodologia husserliana como uma "doutrina de vias redutivas", a via cartesiana do idealismo transcendental mas também, como vimos, uma via genética e do que a autora chama "empirismo transcendental", um movimento de "desobjetivação", pois "aqui se impõe uma redução renovada, que se aplica em desvincular-nos da referência ao objeto. O fio condutor da descrição não é mais o objeto intencional (compreendido na tematização privilegiada do ato que o visa), mas a gênese da vivência do objeto em seu modo de acesso à consciência" (DEPRAZ, 2008, p. 49).
}

\begin{tabular}{|c|c|c|c|c|c|}
\hline intuitio & $\begin{array}{c}\text { ISSN } \\
1983-4012\end{array}$ & Porto Alegre & Vol.10 $-\mathrm{N}^{\circ} .2$ & $\begin{array}{c}\text { Dezembro } \\
2017\end{array}$ & p. 21-51 \\
\hline
\end{tabular}


A Correlação entre a Noção de Subjetividade e o Desenvolvimento do Programa da Fenomenologia em Husserl

permaneça a base sobre a qual deve se fazer o retorno aos fenômenos, o eidos, o aspecto cognoscível não é algo que esteja nele como parte real, mas, justamente, apenas como o ideal na intuição das essências, captável apenas por uma análise da consciência pura, daí a ênfase se encontrar na ideia transcendental de um método purificado que o revele livre de qualquer pressuposto transcendente.

Por outro lado, conforme observado anteriormente, na análise do caminho que leva a fenomenologia ao idealismo transcendental, fica também patente a proximidade temática e espiritual do programa fenomenológico com os problemas herdados da modernidade. Nomeadamente quanto ao projeto de uma filosofia primeira fundada na subjetividade transcendental, a fenomenologia pura pode ser vista como o último grande construto teórico que visa dar conta do ideal de uma "teoria da razão" da fenomenologia em direção a uma forma de idealismo transcendental mostra-se nesse sentido coerente com sua proposta reivindicada de "ciência de rigor". Pois, considerado dessa forma, se há uma orientação idealista do método isso se tornava necessário para que ao cabo este possa se manter fiel ao lema de volta "às coisas mesmas".

Por fim, estes parecem ser também alguns dos motivos da persistência do paradoxo da subjetividade na fenomenologia. Porque, como vimos acima, a subjetividade pura é o pressuposto do qual não se pode abdicar desde que o programa da fenomenologia se converte em metodologia transcendental com pretensão de fundação a priori do ideal de filosofia e ciência. Por isso, o Eu puro e o Ego transcendental se mantém a salvo de qualquer epoché, pois mais do que cumprir o papel de princípio representam para o nível transcendental o próprio movimento inerente a consciência reflexiva, sem o qual a própria ideia de um método descritivo das essências permaneceria ininteligível. Compreende-se, assim também, que não é surpreendente que as investigações fenomenológicas sobre a constituição e, por fim, sobre o próprio pré-dado do mundo da vida remetam a esfera da consciência pura.

Considerado nesse conjunto, podemos então reafirmar que o problema da subjetividade na fenomenologia não se encontra apartado da consideração da fenomenologia enquanto programa de pesquisa, portanto, dos pressupostos sobre os quais se assentam seus fundamentos metodológicos. E, nesse caso, tratar da crítica do tema da subjetividade na fenomenologia significa tratar de uma crítica fenomenológica dos próprios fundamentos da fenomenologia.

\footnotetext{
${ }^{80}$ Conforme afirma Carlos Alberto Ribeiro de Moura, a fenomenologia husserliana é nesse sentido uma "crítica da razão", pois, como vimos, se a fenomenologia é uma "ciência das origens", da "volta às coisas mesmas", isso para Husserl significa antes de tudo não a "origem do ser" mas sobretudo a origem do "conhecimento do ser". "Assim, é apenas essa 'crítica da razão' que figura no horizonte filosófico de Husserl. Apenas ela define o problema da fenomenologia” (RIBEIRO DE MOURA, 1989, p. 37).
}

\begin{tabular}{|c|c|l|l|c|c|}
\hline 1 intuitio & $\begin{array}{c}\text { ISSN } \\
1983-4012\end{array}$ & Porto Alegre & Vol.10- $\mathrm{N}^{\circ} .2$ & $\begin{array}{c}\text { Dezembro } \\
2017\end{array}$ & p. 21-51 \\
\hline
\end{tabular}


A Correlação entre a Noção de Subjetividade e o Desenvolvimento do Programa da Fenomenologia em Husserl

\section{Referências}

HEIDEGGER, M. Prolegomenos para una Historia del Concepto del Tiempo. Madri: Alianza Editorial, 2006.

HUSSERL, E. Investigaciones Lógicas. Madri: Revista do Ocidente, 1976. . Ideas Relativas a una Fenomenología Pura y una Filosofía Fenomenológica. Libro Primero: Introduccción general a la fenomenologia pura. México, D.F.: Fondo de Cultura Econômica, 1986. . Ideas Relativas a una Fenomenología Pura y una Filosofía Fenomenológica. Libro Segundo: Investigaciones fenomenológicas sobre la constitución. México, D.F.: Fondo de Cultura Econômica, 2005. . Meditações Cartesianas. Introdução à Fenomenologia. Porto: Rés, 2001.

2012.

. A Crise da Ciências Européias e a Fenomenologia Transcendental. Rio de Janeiro: Forense Universitária,

SARTRE, J.P. A Transcendência do Ego. Seguido de Consciência de Si e Conhecimento de Si. Lisboa: Edições Colibri, 1994.

DEPRAZ, N. Compreender Husserl. Petrópolis: Vozes 2008.

DESCARTES, R. Meditações. Tradução de J. Guinsburg e Bento Prado Júnior. São Paulo: Abril Cultural, 1973.

MOURA, C. A. R. Crítica da razão na fenomenologia. São Paulo: Nova Stella e Edusp, 1989.

RICOEUR, P. Na escola da fenomenologia. Petrópolis: Vozes, 2009.

SPIEGELBERG, H. The Phenomenological Movement. A historical introduction. Third revised an enlarged edition. Dordrecht/Boston/London: Kluwer Academic Publishers, 1994.

Recebido em: 25/10/2017

Aprovado para a publicação em: 30/11/2017

\begin{tabular}{|l|c|c|c|c|c|}
\hline intuitio & $\begin{array}{c}\text { ISSN } \\
1983-4012\end{array}$ & Porto Alegre & Vol.10- No.2 & $\begin{array}{c}\text { Dezembro } \\
2017\end{array}$ & p. 21-51 \\
\hline
\end{tabular}

